\title{
The Warren Court and the Interstate Commerce Commission
}

\section{Martin Shapiro*}

It has become a commonplace of administrative law that the Interstate Commerce Commission, after long vicissitudes, eventually found a special place in the heart of the Supreme Court. Indeed the preferred position of the ICC is frequently offered as the epitome of that judicial self-restraint in reviewing administrative determinations which budded in the r930's and came to full flower in the forties. While the ICC practitioner may have some lingering doubts about the automatic beneficence of the judiciary, the general student of administrative law, and particularly students of the Supreme Court preoccupied with matters constitutional, are likely to satisfy themselves with the accepted clichés and pass on to more fertile fields of judicial-administrative relations. The clichés of the forties, however, may not fit the governmental behavior of the fifties and sixties. A quick count of the Warren Court ${ }^{1}$ cases indicates that the ICC won only twice as many as it lost and suggests that it might be wise to take another look at what is frequently assumed to be total acquiescence by the Court to the Commission.

The peculiar feature of the Commission is that while most of its individual decisions are quite routine, it has been faced throughout its history with one major problem after another in the transportation industry. The first problem was, of course, the creation of the Commission itself and the struggle to sail the general concept of administrative regulation into the prevailing winds of laissezfaire. Then came the railroad crisis of World War I and the resulting tremors in the twenties, followed by the even worse crisis of the depression. Much of the quietistic case law and administrative experience from which we draw the picture of a maiden aunt commission, tending to her knitting undisturbed, originated in the calmer transportation scene of World War II and its immediate aftermath when the wealth of traffic obscured the fundamental instabilities of the industry. Also, the ICC has indeed perfected its procedures and built an image of fairness-to the extent that courts have been willing to accept its "routine administrative" decisions, particularly on matters of rates and safety. Nonetheless, at the same time the administrative machinery has been cranking out thousands of these routine and judicially-blessed decisions, the Commission has been continuously confronted with major questions that have been anything but routine and have obviously involved crucial national issues of public policy. There is no a priori reason to believe that a judicial deference built up for the former

*A.B. 1955, University of Californja, Los Angeles; Ph.D. 1961, Harvard University. Associate Professor of Political Science, University of California, Irvine.

1. It is always difficult and somewhat arbitrary to define an cra of Court history. I choose to date the Warren Court from the October 1956 term. During that term, Justices Reed and Minton were replaced by Justices Brennan and Whittaker, and Justice Harlan first began to fully participate in the decisions of the Court. 
kinds of decisions would be readily transferable to the latter. To simply say that most ICC decisions are not questioned by the Supreme Court is to ignore what may be a critical distinction between the mass of ICC decisions on tariffs, safety, and accounting practices and those which involve Commission attempts to influence major developments in our transportation system. What is striking is that if we draw up a syllabus of the major contemporary policy questions facing the Commission, we find that the Warren Court has intervened to make some pronouncements on nearly every one.

\section{Questions of Policy}

Undoubtedly the major problem in the transportation area has been the struggle between railroads and the trucking industry. The Supreme Court has handled a number of cases here, ranging from the consideration of whether truck lines ought to be granted certificates initiating competition with railroads in existing markets to questions arising out of piggybacking.

The Warren Court has also dealt with other major policy questions involving the distinction between private, contract, and common carriers-a principal focus of conflict over regulation. Then there are the less crucial but still important problems of rival regulation by state and federal government, shippers' remedies for misrouting, and interpretation of the grandfather clauses that protect a great many truckers. As for railroads, perhaps the principal issue of public policy is what to do with the commuter, and here again the Warren Court has rendered significant decisions. It has also spoken on abandonments and the short haul provisions of the statutes regulating the railroads, both of which are old and continuing problems. Finally, as an illustration of the Court's ability to react quickly to new problems, we encounter the first Supreme Court decision on the seven-month suspension provisions in railroad ratemaking immediately after the railroads abandoned the longstanding gentlemen's agreement to voluntarily suspend new rates until the ICC could reach a final decision.

In the routine areas of rates and tariff interpretation, the Warren Court has seldom intervened, and apparently then only because the Government was involved as shipper. But the rate problems of the ICC have undergone a radical change. Nearly all its important rate business is now focused on requests for rate reductions-reductions to meet competition, usually from a rival mode of transportation. In this crucial rate area the Court has intervened. Moreover, it has also intervened in rate disputes when they were, in effect, not simple matters of fair return, but part of the commuter problem.

The only major area of transportation policy in which the Court has not been active is that of mergers. The Court long ago contributed its bit of encouragement by allowing the Commission to deviate from antitrust policies. Neither Court nor Commission seems to be playing a particularly active role, although we shall touch upon a few peripheral decisions. Court inactivity here is less a matter of deference to other government agencies than part of the general government inactivity in this area. Truck line mergers and other forms of trucker cooperation, however, apparently are beginning to worry both the Commission and the Court. 
Of course, in saying that the Warren Court has spoken on every crucial issue of transportation policy except mergers, and on many less crucial but nonetheless important questions, I am not necessarily suggesting that the Court has been engaged in seizing policy initiative in most areas of the transportation field. Frequently the Court speaks only to echo the Commission or to make some minor adjustment in statutory interpretation. However, it has always been the nature of statutory interpretation by the judiciary, particularly when the conduct of administrative agencies is involved, to create the appearance of minimum judicial intervention no matter what the actual level. Courts are quite capable of leading without producing leading cases. It is, therefore, necessary to examine each of the Court's pronouncements, big and little, in each area of transportation policy in order to assess the extent of judicial influence. We begin such a survey with no expectation of judicial imperialism, but with an awareness that we are dealing with a body of law from which the Court has not chosen to withdraw to anywhere near the extent that has often been suggested.

\section{The Attitudes of the Justices}

Before turning to a survey of the cases and their impact, it might be well to examine briefly the attitudinal patterns of the individual Justices in the transportation cases. Let me make clear at the start that I am not trying to contribute to the growing body of literature which attempts to reduce judicial behavior to a relatively small number of attitudes that can be charted through various sociological and psychological techniques and then be shown to explain all or most of the decisions. ${ }^{2}$ I am only seeking to apply whatever insights the judicial behaviorists may have had to the problem before me. In short, while the work of the attitudinalists may contribute something to this study, this study is not going to contribute much to the work of the attitudinalists.

The body of case material that charts the relations of the Court to the Commission is basically unsuitable for eliciting a clear pattern of judicial attitudes. First, a large share of the cases are unanimous or nearly unanimous and thus do not serve to differentiate attitudes. ${ }^{3}$ Secondly, the total number of cases is not large enough to inspire even that rather arbitrary faith in tests of statistical significance that appear in the attitudinal studies. Thirdly, and most important, the factual situations in the cases simply do not present themselves so as to promote the revealing of attitudes. This point is not made simply as a methodological aside. It is crucial to an assessment of the actual work of the Court, particularly to the question of whether the Court has been working or should work in what Llewellyn called the "grand style."

2. See Schubert, Bibliographical Essay, Behavioral Research in Public Law, 57 Ax. PoL. Scr. Rev. 433 (1963); Shapiro, Political Jurisprudence, 52 Ky. L.J. 294, 307-16 (1964).

3. See Schubert, The Study of Judicial Decision-Making as an Aspect of Political Behavior, 52 AM. Por. Scr. Rev. 1007, 1016 (1958).

4. See Llewellyn, The Common Law Tradition-Deciding Appeals 62-75 (1960). While Llewellyn's concept of the grand style is complex and requires careful study, basically he is concerned with decisions grounded on politico-socio-economic reality rather than on mechanical use of precedent. 
Attitudinal research indicates that the Justices may be ordered along a scale of attitudes toward business which dominate their decisional behavior in the whole range of cases involving government regulation of business. At one end of the scale are those Justices who are pro-business in the sense of voting against government regulation. ${ }^{5}$ On the other end are those who are anti-business in the sense of approving government regulation. Some of the ICC cases can be fitted into this analysis, but most cannot. To the extent that there is a typical ICC case, it involves a dispute between one transportation firm and its actual or potential competitors or between two competing modes of transportation. All of these parties, moreover, are highly regulated so that the dispute is usually one in which each side is attempting to exploit the regulation of the other to its own advantage. It is not at all clear how a judge with strong pro-business attitudes could be influenced by them in a case which actually is a dispute between truckers and railroaders, even though it is nominally titled American Trucking Ass'ns v. United States.

A few modest things can be said about judicial attitudes toward the ICC. In toto the Commission won about nineteen and lost about eleven of the cases we are considering. ${ }^{6}$ In view of Professor Tanenhaus' earlier findings that the Court does not particularly favor the ICC, ${ }^{7}$ these figures do not lead to any general statement about the Court's attitude other than the initial one that the Court is not passive in this area. The summary figures, however, do serve as a basis for the only firm statements we can make about the attitudes of individual Justices. It is worth one table to present these. ${ }^{8}$

\begin{tabular}{|c|c|c|}
\hline & Pro-ICC & Anti-ICC \\
\hline 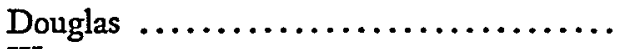 & 9 & $2 I$ \\
\hline Warren $\ldots \ldots \ldots \ldots \ldots \ldots \ldots \ldots \ldots \ldots$ & 13 & I7 \\
\hline Black..$\ldots \ldots \ldots \ldots \ldots \ldots \ldots \ldots \ldots \ldots \ldots \ldots$ & I3 & I7 \\
\hline Clark.$\ldots \ldots \ldots \ldots \ldots \ldots \ldots \ldots \ldots \ldots$ & 15 & I5 \\
\hline 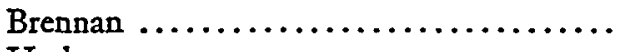 & I3 & 12 \\
\hline Harlan $\ldots \ldots \ldots \ldots \ldots \ldots \ldots \ldots \ldots$ & 20 & Io \\
\hline Stewart $\ldots \ldots \ldots \ldots \ldots \ldots \ldots \ldots \ldots \ldots$ & 14 & 6 \\
\hline Whittaker...$\ldots \ldots \ldots \ldots \ldots \ldots \ldots \ldots \ldots$ & II & 5 \\
\hline Burton $\ldots \ldots \ldots \ldots \ldots \ldots \ldots \ldots \ldots \ldots \ldots$ & 8 & 2 \\
\hline Frankfurter $\ldots \ldots \ldots \ldots \ldots \ldots \ldots \ldots \ldots$ & 17 & 2 \\
\hline
\end{tabular}

5. Spaeth, Warren Court Attitudes Toward Business: The "B" Scale, in Judran Decision MakING 79 (Schubert ed. 1963).

6. Since I am not going to use any tests of statistical significance, these approximations are good enough. The "about" is a warning that in a few instances the choice of how to pigeonhole a particular case is rather arbitrary. Occasionally, for instance, the ICC will win its rule in Court but not its remedy. Cases expanding the Commission's jurisdiction or protecting it from jurisdictional incursions by other agencies are scored for it, although in one of these instances the Commission itself had argued for the jurisdiction of the other agency. I have not included schedules of the cases and exactly how they were scored because, as I have already noted, the table below is suggestive rather than statistically significant.

7. Tanenhaus, Supreme Court Attitudes Toward Federal Administrative Agencies, 14 Vand. L. Rev. 473 (1961).

8. The following additional scores were omitted from the table because of the lack of sufficient data to reach a meaningful conclusion: Goldberg 4-6; White 6-5.

9. The phrase "pro-ICC" is used throughout this Article to describe a vote or attitude favoring the Court's upholding of Commission decisions. It does not necessarily suggest approval of Commission 
On the basis of this table, it is certainly possible to propose a pro-ICC wing of the Court. Indeed the attitudinal break is somewhat sharper than the figures suggest. For instance, of Harlan's ten anti-Commission votes, six were in unanimous decisions where presumably the Commission's legal position was clearly dubious. ${ }^{10}$

It has been argued, again on the basis of a far broader and thus presumably more reliable sample of the Court's work than offered here, that attitudes toward business, not agencies, are the dominant variable in the business regulation area. ${ }^{11}$ As we have already noted, this proposition is difficult to test in the ICC cases because so many involve businesses on both sides. I have therefore divided the cases into two groups. In the first group (Group A) are those cases in which a clear business versus government conflict can be identified, and in which the Justices' attitudes can be more clearly defined. ${ }^{12}$ In the second (Group B), two businesses are actually in conflict, but I have scored as pro-business those cases in which the Court allowed one of the businesses to do what it could have done without government permission if the ICC had not existed. In other words, a vote to give business freedom of action is scored pro-business. ${ }^{13}$ In these cases attitudes are less clearly defined, but some decisional patterns are observable.

In the Group A cases none of the Justices on our table from Harlan down to Frankfurter ever voted against the Commission whether it decided for or against business, ${ }^{14}$ except in one case decided unanimously against the business and the Commission. ${ }^{15}$ In Group B, although the number of cases is very small, there is no noticeable tendency in the Harlan-Frankfurter faction either to support the Commission when it allowed the business to do what it wanted or to oppose it when it did not. In Group A cases the ICC had generally supported business, so that pro-business sentiment and diffidence to the ICC are difficult to distinguish. Nevertheless, the fact that all five Justices involved faithfully upheld the ICC in

policy, but may only be the expression of the Court's refusal to question the judgment of an expert agency. Conversely "anti-ICC" describes votes or attitudes which favor reversing Commission decisions. The term does not necessarily indicate disapproval of Commission policy but may be used where the Commission has exceeded its statutory authority.

10. A seventh decision falls in roughly the same class, an 8-to-1 vote, with Frankfurter the lone dissenter. On the other hand, the pro-ICC scores of Whittaker, Burton, and Frankfurter may appear to be higher than they otherwise would have been, because all three Justices left the Court before the four cases of the 1962 and 1963 terms that were decided unanimously against the Commission.

11. See Spaeth, supra note 5, at 100.

12. It may be, of course, that in these cases the Justices are governed by cconomic attitudes, but the same case may appear to one pro-business Justice to require affirmation, and to another, reversal. On the other hand, these cases present difficult and uncertain questions of public policy and will probably produce ambiguity of decisional patterns whether or not fixed economic attitudes are in play. Moreover, it may be that when business clashes with business, pro-business and pro-Government attitudes are not brought into play, and the Justices make genuinely neutral policy decisions.

It might be possible to better differentiate the Justices by categorizing their votes as for or against competition, for or against carriers, etc. I have experimented with several of these, particularly one based on carrier versus shipper interest, without success. In any event such categorizations would require precisely those involved and subtle legal judgments about the content and thrust of opinions that attitudinal analysis seeks to avoid.

13. For instance, when a railroad wishes to cut its rates to compete with a barge line, a vote for the railroad is scored as a pro-business vote even though it is also a vote for competition and in fact a vote for one business and against another.

14. The pro- and anti-business votes of these Justices in Group A cases are: Harlan 7-4; Stewart 3-3; Whittaker 4-2; Burton 4-1; Frankfurter 6-2.

15. Chicago, M. \& St. P.R.R. v. Illinois, 355 U.S. 300 (1958). 
all but one case suggests that a pro-ICC attitude rather than a pro-business attitude is operative here. ${ }^{16}$

Having identified a pro-ICC wing of the Court, it is necessary to determine whether there is also an anti-ICC wing. ${ }^{17}$ Certainly Douglas might be in this category, though Brennan and Clark certainly are not. It would be misleading to label Black and Warren as anti-Commission on the basis of their deviation from the ro-II overall Court record, since that record is obviously heavily influenced by the extreme deference of the pro-Commission wing. Here again the question arises whether we are dealing with an attitude toward the Commission or toward business. In the decisions that can be clearly labeled pro- or anti-business, Douglas, Black, and Warren show a strong anti-business tendency, while Brennan and Clark split about evenly. With the exception of one vote by Douglas, all five have disagreed with the Commission in these Group A cases only when the Commission decided in favor of business. Again, in Group B no clear pattern is discernable.

Therefore, without any precise statistical conclusions, which the nature and number of cases could not in any event support, I would suggest that the Court has been roughly divided into two wings. One is highly deferent to the ICC, although that deference may in part be a function of pro-business attitudes shared by those Justices and the Commission. The other wing is, with the possible exception of Douglas, neither particularly deferent nor particularly hostile to the Commission; when conflict arises it is largely because of somewhat differing views toward business. The intermediate position of Clark and Brennan on deference to the Commission corresponds to their intermediate attitudes toward business.

Having tentatively identified two Justices who share neither the deference toward the Commission of the Harlan-Frankfurter wing nor the hostility toward business of the Douglas-Warren wing, we might consider whether they perform a "swing Justice" role. ${ }^{18}$ Of the cases to be considered, ten were decided 5-to-4 or 6-to-3. In six of these the Douglas-Warren bloc was opposed by the Harlan-Frankfurter bloc with Brennan and Clark giving the voting edge to Douglas-Warren. ${ }^{19}$ In one case the Frankfurter-Harlan wing was in the majority because it was

16. This analysis suggests that Justice Frankfurter's canons of decision may have been so complex and have varied so greatly between various areas within the Court's jurisdiction that summary statements based on a large number of his decisions in many areas may obscure more than they enlighten. Certainly when mixed with other sorts of cases, his ICC decisions would indicate the existence of pro-business attitudes, but when analyzed individually they tend to suggest that in this area at least he stuck firmly to judicial restraint (or as I prefer to call it, judicial modesty). For a contrary suggestion see Spaeth, supra note 5 , at 100.

17. See note 9 supra.

18. Spacth identifies Clark as the swing Justice in his broader category of "business regulation" cases. Spaeth, supra note 5 , at 89.

19. One of the six presents the anomaly of Harlan, Whittaker, and Burton voting against the Commission while the Warren bloc stood with it. Consequently Frankfurter voted with the Warren bloc making it 6-to-3. See Pan-Atlantic S.S. Corp. v. Atlantic Coast Line R.R., 353 U.S. 436 (1957). The other cases are Red Ball Motor Freight, Inc. v. Shannon, 377 U.S. 311 (1964); Hewitt-Robins Inc. v. Eastern Freight-Ways, Inc., 371 U.S. 84 (1962); ICC v. J-T Transp. Co., 368 U.S. 81 (1961); Public Serv. Comm'n v. United States, 356 U.S. 421 (1958); County of Marin v. United States, 356 U.S. 412 (1958).

The phrase "Harlan-Frankfurter bloc" is used for convenience here. In fact Frankfurter had retired from the Court before Red Ball and Hewitt-Robins were decided. 
joined by Clark and Brennan. ${ }^{20}$ In another it prevailed because it was joined by Brennan. ${ }^{21}$ The ninth and tenth do not fall along convenient lines of bloc voting. ${ }^{22}$ It would appear, therefore, that Brennan and Clark are in a sense swing Justices, but this phenomenon should not be overemphasized in view of the high proportion of unanimous or near unanimous cases in this area. ${ }^{23}$

Viewing the Court as a whole, in Group A cases the ICC won 6 and lost 2 when it decided in favor of business, and won 4 and lost 0 when deciding against. In Group B cases the Commission won 3 and lost 3 when it adopted a permissive attitude, and won 3 and lost 3 when it attempted to regulate. Here again it is in the crucial area of intercarrier rivalry that statistics give us the least comfort.

It remains to examine individual attitudes toward the various types of carriers. Again a brief table is in order. ${ }^{24}$

\section{Pro-Railroad Pro-Other Carriers}

\begin{tabular}{|c|c|c|}
\hline Douglas . & 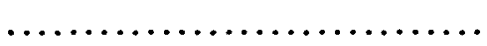 & 2 \\
\hline Warren & $\ldots \ldots \ldots \ldots \ldots \ldots \ldots \ldots \ldots \ldots \ldots$, & 2 \\
\hline Black ... & $\ldots \ldots \ldots \ldots \ldots \ldots \ldots \ldots \ldots \ldots \ldots \ldots$ & 2 \\
\hline Clark ... & 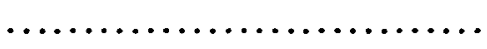 & 2 \\
\hline Brennan & $\ldots \ldots \ldots \ldots \ldots \ldots \ldots \ldots \ldots \ldots \ldots \ldots \ldots \ldots \ldots$ & 4 \\
\hline Harlan .. & 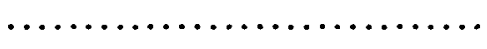 & 5 \\
\hline Stewart & 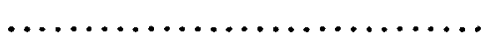 & 3 \\
\hline Whittaker & a $\quad \ldots \ldots \ldots \ldots \ldots \ldots \ldots \ldots \ldots \ldots \ldots \ldots$ & 3 \\
\hline Burton . & 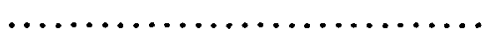 & 2 \\
\hline Frankfurt & $\operatorname{ter} \ldots \ldots \ldots \ldots \ldots \ldots \ldots \ldots \ldots$ & 3 \\
\hline
\end{tabular}

In the cases presented in this table, where the railroads and some other transportation medium are in conflict, the clearest indication of attitudes emerges from the record of those Justices who pay no particular deference to the ICC. We thus find that Warren, Black, Douglas, and Clark (but not Brennan) show relatively strong anti-railroad tendencies. ${ }^{26}$ As for the deferential wing, all of Frankfurter's and Stewart's pro-railroad votes were also pro-Commission votes, as were three out of Harlan's five. On the other hand, roughly three-fourths of the total votes against railroads cast by Stewart, Harlan, Whittaker, Burton, and Frankfurter were anti-Commission votes. This suggests either that their pro-Commission voting is caused by something other than deference to the ICC, or that they are just as anti-railroad as their colleagues but that those sentiments are frequently overcome by their deference to the Commission.

20. See Alleghany Corp. v. Breswick \& Co., 353 U.S. 151 (1957).

21. See A. L. Mechling Barge Lines v. United States, 368 U.S. 324 (1961).

22. See All States Freight, Inc. v. New York, N.H. \& H.R.R., 379 U.S. 343 (1964); Arrow Transp. Co. v. Southern Ry., 372 U.S. 658 (1963).

23. Of the thirty-one cases examined, twenty-one had two or less dissenters.

24. The following additional scores were omitted from the table: White 2-1; Goldberg 2-1.

25. All States Freight, Inc. v. New York, N.H. \& H.R.R., 379 U.S. 343 (1964), is not included in this table because while nominally a railroad versus truck case it is equally a railroad versus railroad case.

26. Care must be taken in these cases not to confuse anti-business sentiment with anti-railroad sentiment. 


\section{The Significance of Attitudes}

What difference does all this make? In one sense, none. If, for example, the Court reads the transportation statutes as forbidding the ICC to reduce the scope of operations of a former contract carrier now applying for common carrier status, the ICC will have to abandon those reductions whether three Justices are voting anti-ICC and three, pro-business, or all are voting on the basis of independent considerations. In short, it is the position of the Court as embodied in the legal doctrine it enunciates, rather than the attitudinal components of the individual Justices which go into making the doctrine, that is the effective political influence upon the behavior of those agencies required to heed the Court's pronouncements. ${ }^{27}$

Nevertheless, agencies will adapt their behavior not only to the past decisions of the Court, but to what they anticipate the future ones will be. Such anticipation necessarily rests as much on analysis of judicial attitudes as on logical extrapolation from existing doctrines. Moreover, when Court opinions are vague, incomplete, or confused, their attitudinal components may help to clear up their real thrust. Particularly in administrative law, attitudes toward an agency may have a very pronounced effect. Let us suppose the Court directs the ICC to consider factor $X$ in reaching its decisions on railway abandonment. The ICC may nevertheless go on effectively ignoring factor $X$ while paying lip service to it, so long as the Commission knows that a majority of the Justices entertains such a high degree of deference toward the Commission that they will not overturn its decisions unless the Commission blatantly transgresses statutory provisions. Where a court usually confines itself to prescribing the factors to be considered by an agency and the decisional rules to be used, cases will turn on just how active a part a majority of the judges are willing to play in enforcing the spirit as well as the letter of the court's pronouncements. The attitudinal patterns of the judges, moreover, may determine which sorts of rules are actively enforced and which merely receive formal promulgation.

In analyzing Court-ICC relations, the attitudinal analysis above will be useful in identifying factors that require special attention and might otherwise be ignored. For example, in those cases involving disputes between railroads and trucks the fact that a group of pro-ICC Justices vote against the Commission when it favors railroads indicates that there may be more to the anatomy of judicial modesty usually found in the area than mere deference to the Commission. The large number of unanimous decisions and the swing role played by two Justices who have no particularly strong attitudes toward the Commission or the carriers suggests that the grand style may be at work. The identification of Clark and Brennan as swing Justices, of course, leads to special concern with their attitudes in cases where their votes were decisive. Justice Frankfurter's attentive courtship of the ICC suggests that to the extent his opinions rest on interpretation of the statutes rather than open deference to the Commission, they should be taken with a grain of salt. Finally, attitudinal findings of other com-

27. This is, of course, a relative statement. The more vague the Court's opinions the more likely agencies are to govern their behavior by attitudinal analysis. 
mentators plus the mildly anti-business tendencies evident in the Douglas-Warren group should provide insights into cases presenting a simple conflict between government and business.

\section{Ramroads Versus Trucks}

The principal involvement of the Supreme Court in the conflict between railroads and truck lines has been in cases dealing with railroad-owned truck lines. Faced with increasing truck competition, many railroads in the postwar period have sought to fight fire with fire by beginning new trucking operations or expanding existing ones. There are no specific statutory provisions governing such activity, and this whole area has been characterized by a high degree of administrative and judicial lawmaking. Initially the ICC read into the merger provisions of the Motor Carrier Act of 1935 the implication that railroads might only gain control of truck lines offering "auxiliary and supplementary" service to the rail line. ${ }^{28}$ The precise meaning of "auxiliary and supplementary" was never really clear, although basically the phrase applied to the replacement of "way cars" by trucks and door-to-station motor carriage of freight for which the long haul was by rail. ${ }^{29}$ The ICC attempted to reserve to itself maximum discretion over the meaning of the phrase, ${ }^{30}$ although it was reversed by the Court when it sought to declare as a matter of public policy that a railroad might not arrange through routes consisting partly of carriage by rail and partly of carriage in its own trucks. Nevertheless, the Commission was generally so pleased with the auxiliary and supplementary rule that it extended it from the merger provisions (section 5 of the Interstate Commerce Act) to the general certification provisions (section 209). ${ }^{31}$ Since the rationale for the auxiliary and supplementary rule was to avoid the peculiarly anticompetitive effects of mergers, the extension of the rule to nonmerger situations was a rather bold, although hardly unusual, piece of administrative lawmaking.

The establishment and extension of the auxiliary and supplementary rule stemmed from the Commission's desire to protect truckers against railroads in accord with the obviously pro-truck thrust of the Motor Carrier Act and the National Transportation Policy, ${ }^{32}$ both of which had been passed when the truckers were David and the railroads, Goliath. But the Commission found that a rule designed as an ironclad support for truckers might in certain cases simply

28. See American Trucking Ass'ns v. United States, 355 U.S. 141, 147-48 (1957), and cases cited therein. The merger provision of the Motor Carrier Act authorized ICC approval of railroad mergers, consolidations, or acquisition of control where "the transaction proposed will promote the public interest by enabling such carrier other than a motor carrier to use service by motor vehicle to public advantage in its operations and will not unduly restrain competition." Motor Carrier Act \$ 213 (a) (1), added by ch. 498, \$1, 49 Stat. 555 (1935) (now Interstate Commerce Act \$5(2)(b), added by 54 Stat. 905 (1940), as amended, 49 U.S.C. $\$ 5$ (2) (b) (1964)).

29. See Hearings on S. 3606 Before a Subcommittee of the Senate Committee on Interstate Commerce, 75th Cong., 3d Sess. 23 (1938). The way car is shuttled from small station to small station along the right of way, picking up minor shipments until it finally arrives at a main terminal where its contents are loaded on through cars for shipment to their destination. Trucks frequently provide a cheaper and more flexible method of handling this freight.

30. See E. Brown, The Supreme Court 1957 Term, 72 HaRv. L. Rev. 77, 122 n.119 (1958).

31. See American Trucking Ass'ns v. United States, 364 U.S. 1 (1960).

32. See text accompanying note 54 infra. 
force railroads into inefficient operation or lead to deficient carrier service without any countervailing advantage to motor carriers. Thus the Commission refused to apply the auxiliary and supplementary rule where it found "special circumstances" in both merger and nonmerger situations.

In the postwar period, however, the actual transportation situation began to correspond less and less with that for which the original statutes had been drawn. The truck business was expanding and the railroads were losing traffic to motor carrier competition. The Commission's earlier vagueness about just what auxiliary and supplementary meant and its special circumstances rule both began to pay off in a new way. The Commission could begin to load the scales against truckers or at least hold the balance equal without having to openly confess that it was changing the initially anti-railroad thrust of the Motor Carrier Act and National Transportation Policy in the face of new circumstances. This could be done simply by giving the loosest possible definition to "auxiliary and supplementary" and by being particularly liberal in finding "special circumstances." By these means railroad expansion into the motor field could be favored under rules initially devised for the opposite purpose.

In $195^{8}$ the rather strange case of American Trucking Ass'n v. Frisco Transp. $\mathrm{Co}^{33}$ indicated the change in Commission policy. We shall deal with the technical aspects of the case later. What is important at this point is that here the Commission pushed the liberalization of its policy toward railroad-owned truck lines to the point of arguing that a clause in a certificate permitting the Commission to add restrictions at some future date was sufficient to meet its policy of issuing only restricted certificates. ${ }^{34}$

The applicability of the auxiliary and supplementary criterion to nonmerger cases had never reached the Supreme Court. It did so in the context of the Commission's new liberalization drive which was being strongly opposed by the independent truck operators. In American Trucking Ass'ns v. United States ${ }^{35}$ a railroad had received ICC approval of a merger with a truck line, subject to the normal auxiliary and supplementary restrictions. Subsequently, as a rail-owned truck line, it had applied for and received a regular certificate under section 207 of the Motor Carrier Act, but without such restrictions. The ICC, having stretched the statutory language originally to pull the auxiliary and supplementary requirements out of section 5 and then even more so to extend them to section 207, now wanted to stretch the language still further to justify using the auxiliary and supplementary rule at its discretion. This was a particularly tricky problem for the Commission because the auxiliary and supplementary rule rested largely on the "longstanding practice" doctrine. ${ }^{36}$ In effect, if the Commission wished to maintain the auxiliary and supplementary rule at all, it had to say that it was a

33. 358 U.S. 133 (1958).

34. The issues in the case were not shaped so as to require a ruling on this argument. It was, however, later rejected by the Court in American Trucking Ass'ns v. United States, 364 U.S. 1 (1960).

35. 355 U.S. 141 (1957).

36. The Supreme Court frequently is willing to invest the longstanding practice of an administrative agency with the force of law, believing that if Congress had not intended the practice it would have cnacted new legislation. 
rule of law because of consistent, longstanding practice, even though the Commission was no longer going to apply the rule consistently.

This sort of legal illogic is, of course, not uncommon when a lawmaking agency is attempting to alter the law to meet a new situation without totally abandoning an earlier and hard-fought-for legal position. The Supreme Court opinion was a magnificent save for the ICC, providing it with almost precisely the degree of flexibility the Commission desired. The Court first found that the auxiliary and supplementary requirement had indeed become a rule of law under the merger provision of section 5. It then found that Congress had not intended the requirements of that section, including the auxiliary and supplementary requirements, to be read bodily into the nonmerger provisions, but that they were to be taken only as a "guiding light." In short, the Commission was to have its cake and eat it too. The auxiliary and supplementary requirement was for mergers a rule of law that the Commission need not enforce when it found special circumstances; in section 207 cases, however, the rule could be applied or not applied at will. Moreover, as this case indicates, where the Commission and carrier wished to avoid the auxiliary and supplementary requirements even for mergers, the Commission need only grant a restrictive certificate modification of which, subsequent to merger, would be treated as a section 207 matter.

The Court treated the issuance of a certificate unrestricted by auxiliary and supplementary requirements in this instance as being within the special circumstance exception to the auxiliary and supplementary rule. In thus giving the Commission broad discretion, however, the Court was careful to reserve for itself the power to decide in each instance whether the Commission was properly using its special circumstances criterion.

The second American Trucking case ${ }^{37}$ suggests that this reservation was something more than a gesture. Here again we meet with a Commission attempt to develop the law. Superficially the key feature of the auxiliary and supplementary rule would appear to be the requirement that truck services be performed only to and from points along the rail line. Where trucks are replacing way cars, they move from point to point along the line. Where they are picking up or delivering freight whose long haul is by rail, they move from door to rail terminal and vice versa. In the second American Trucking case the Commission issued a certificate restricting truck destinations to points along the rail line. Now, of course, logically speaking this was to confuse a superficial feature with the "true principle" of earlier Commission decisions. What makes trucking service auxiliary and supplementary is not that the trucks come and go from points along the rail line, but that their operation is an integral part of the rail movement of freight. Otherwise a railroad that had terminals in Los Angeles and San Francisco could run a general trucking service between those two cities and claim it to be auxiliary and supplementary because the trucks came and went from points along its line. It is precisely this logical flaw that marks the attempt to alter the law to meet changing circumstances. The Commission was obviously attempting to preserve the semblance of its auxiliary and supplementary rule while in fact

37. American Trucking Ass'ns v. United States, 364 U.S. 1 (1960). 
opening up another avenue in addition to the special circumstances exception by which it might allow railroads to fight trucks with trucks. ${ }^{38}$ If the Commission could satisfy section 205 simply by limiting rail-owned truck lines to operations between destinations served by the railroads, it would be allowing the railroads to enter the general trucking market at precisely the points where the truckers were cutting into rail revenues most heavily. This device would be even more effective than the special circumstances rule. That rule being an exception to the general restriction requirement set by the guiding light of section 5 , the Supreme Court may decide in each instance whether the circumstances warrant such an exception. Once the Court were to admit, however, that a geographic limitation alone met the restriction requirements of the statute, the Commission would be free of Court supervision whenever it imposed such a limitation. ${ }^{39}$

The Supreme Court was not willing to allow the Commission to go so far. It refused to allow the shift from functional to geographic criteria, pointing out that to do so would destroy the real thrust of the auxiliary and supplementary rule. It stressed that the purpose of the National Transportation Policy was to avoid the further expansion of railroads into the general trucking business, and it noted that the Commission had not found special circumstances to justify lesser restrictions than those normally applied under the auxiliary and supplementary rule. It also refused to accept the Commission's maneuver of inserting a provision in the certificate allowing future restrictions and claiming that such a provision itself constituted a sufficient restriction to meet the statutory requirements.

In one sense the Court's opinion may simply have been an instruction to the ICC as to how to write its opinions. The Commission had made no attempt either to say that the geographic limitations imposed amounted in substance to an auxiliary and supplementary requirement or to allege special circumstances warranting an exception to the auxiliary and supplementary rule. Perhaps the Commission might have accomplished the result it wanted simply by invoking one of the hallowed formulas, and the Court was insisting on no more than that. But I think this would be an overly narrow reading of the case. The crucial point is that the ICC was attempting to take one more step toward total discretion in applying the auxiliary and supplementary rule, and the Court was refusing to allow the Commission to take that step. The Justices were thus actively intervening in the policymaking process to prevent the ICC from developing a new discretionary power which could be used to aid the railroads against truck competition. ${ }^{10}$

38. The Commission sought to anticipate hostile reaction to its novel position by stating in its opinion that the case was so unusual that the decision was to be confined to its facts. But this was, of course, simply a defensive gesture, for the decision could serve as precedent for deviating in the future from the auxiliary and supplementary rule in other unusual cases. Moreover, such saving clauses have a habit of conveniently disappearing from view when decisions are cited later.

39. The Court might always find other hooks on which to hang intervention, but the Justices are obviously in a far better position when dealing with an exception to the accepted rule than with an application of the accepted rule.

40. The Commission has subsequently taken the position that its auxiliary and supplementary requirement can be altered only by congressional action, but it has not pressed for such legislation. See Buland \& Fuhrman, Integrated Ownership: The Case for Removing Existing Restrictions on Com- 
The vote in the first American Trucking case was 8-to-I, with only Douglas dissenting. The second American Trucking decision was unanimous, Frankfurter casting one of his two votes against the Commission in the period under study. From the survey of attitudes presented above, however, it might well be concluded that the unanimity of the voting disguises two quite different approaches. In the first American Trucking case the modest wing of the Court may have deferred to the Commission's expertise as reflected in longstanding administrative practice, while the more activist Justices presumably approved of the Commission's general position in balancing the interests of railroads and truckers. For the activists, the second American Trucking case seems to be based on a policy judgment opposing liberalized movements of railroads into the general trucking business. For the modest, the decision is somewhat more complex and revealing.

Judicial modesty has two roots. One develops from a general lack of confdence in the abilities of appellate judges and emphasizes deference to other more skilled or better placed decision makers-administrative experts, trial court judges, local authorities, et cetera. The other is derived from a mixture of naive Austinian positivism and simplistic democratic theory. The legislature is the voice of the people and the commands of the legislature should therefore be given the greatest possible force, with judicial or administrative lawmaking reduced to an absolute minimum.

These two aspects of modesty are likely to collide in cases involving the regulatory commissions, particularly if and when Commissioners as administrative experts seek to alter or update outmoded Congressional enactments by liberal doses of administrative lawmaking. The Harlan-Frankfurter wing of the Court is likely to defer to the Commission when all that is involved is allegedly unfair treatment of one of the parties, but it may oppose the Commission if it appears that the Commission is not obeying the commands of Congress, no matter how old and inappropriate these commands might seem. Thus when the Commission is attempting to create new policy that is not in line with the views of the DouglasWarren wing and is inconsistent with the enabling statutes, it is likely to lose by a unanimous vote because some of the Justices oppose administrative policymaking and others oppose the substance of the administrative policy made. Curiously, then, the impact of the modest wing's voting in these cases is likely to be an increase in the Court's influence over transportation policy through a united front of Justices against any new Commission policies that are inconsistent with relevant statutes and that the Douglas-Warren wing do not like.

This is certainly true in the second American Trucking case where the Commission's attempt to alter the Motor Carrier Act and the National Transporta-

mon Ownership of the Several Forms of Transportation, 31 Geo. WASH. L. REv. 156, 177-81 (1962). Presumably it still wishes to preserve the power to impose heavy restrictions on railroads even though doing so results in reduced flexibility for the Commission. The Commission may well feel that the auxiliary and supplementary rule with the special circumstances exception, even when policed by the Court, gives it more discretion than would repeal of the auxiliary and supplementary provisions. Repeal would permit freer entry into the trucking business than would the marginal adjustments desired by the Commission. 
tion Policy to fit the changed balance of power between trucks and railroads was blocked by a combination of the judicially modest and the activists whose overall voting indicates a relatively strong policy bias against the railroads. We shall find this phenomenon recurring in other cases.

A pattern very similar to that of the two American Trucking cases can be discerned in Schaffer Transp. Co. v. United States. ${ }^{41}$ Here a motor carrier asked for certificates extending its routes to points previously served only by rail. The ICC refused the certificates, finding that the railroad service available was adequate to meet the needs of shippers and that shippers desired motor service only to obtain the lower rates offered by the truckers. The ICC had, of course, been handling this sort of case since the passage of the Motor Carrier Act. The Commission's initial and longstanding policy had been that the existence of adequate rail service was not in itself sufficient to deny a certificate to a motor carrier. Indeed, it frequently ignored rail service altogether and issued motor certificates simply on a showing that no other motor service to the point existed. ${ }^{42}$ Later the Commission began to consider the existence and adequacy of rail service as one factor in determining whether public convenience and necessity warranted motor service. ${ }^{43}$ Schaffer represents the final shift in the Commission's position to a ruling that the adequacy of rail service may alone be sufficient to deny a certificate to a motor carrier. ${ }^{44}$

Here again it is quite obvious that the Commission has been altering established doctrine to meet the new balance of power between railroads and trucks. It is significant that one of the routes involved in this case would have allowed trucks to tap the Vermont stone market at a rate lower than that of the railroads. Vermont marble along with Maine potatoes, where the trucks are also beginning to hit hard, are the last mainstays of even minimal economic health for the northern New England railroads.

The Court refused to allow the Commission this sort of major change in the statutory scheme. It held that the National Transportation Policy, which requires that the "inherent advantages" of each mode of transportation be preserved, applied to the certification provisions of the Motor Carrier Act, that the Commission had considered only the adequacy of railroad service and not the possible inherent advantages of trucks, and that lower rates might themselves be an inherent advantage. Here again the decision may be read as simply an instruction to the ICC as to how, or at least how not, to rationalize its decision in a given case. ${ }^{45}$ But at the doctrinal level the Court again prevented the Commission from altering the law from a basically pro-truck to a basically pro-railroad orientation. And the Court reserved the right to chastise the Commission if in future cases it should seek to pay only lip service to the established doctrine. The inherent threat of future intervention to insure that its doctrine is obeyed is strongly

41. 355 U.S. 83 (1957). See also ICC v. J-T Transp. Co., 368 U.S. 81 (1961), discussed in text accompanying notes $102-04$ infra.

42. Sec, e.g., Petroleum Transit Corp., 3 M.C.C. 607, 609 (1937).

43. See E. Brown, supra note 30 , at 126.

44. The Commission language was somewhat cloudy on the point, but undoubtedly a decision for the Commission in Schaffer would have been fairly read as precedent for this position.

45. Buland \& Fuhrman, stipra note 40, at 169-74. 
backed by the voting of the Court. For in Schaffer, too, the vote was nearly unanimous. Only Frankfurter returned to the side of the Commission with the usual modest defense of wide discretion for administrative agencies.

These three certification cases do not tell the whole story of trucks versus railroads before the ICC and the Supreme Court. We shall return to this battle as well as that between rail and water carriers when we consider intermodal rate cutting. Nevertheless, the rail-owned truck line cases do allow us to isolate the rail-truck conflict from other considerations. One authority, in summing up the problem, indicates that the only major ICC deviations from its auxiliary and supplementary rule have come in the two instances that led to the two American Trucking decision ${ }^{46}$ and that these two instances were obviously important Commission thrusts to open up new lines of maneuver. We can therefore conclude with some certainty that the Supreme Court is maintaining a very active presence in the major rail-truck battle. In maintaining that presence the Court is acting with decisive economy by intervening from the beginning in those cases where another decision maker is attempting a major shift in the development of the law or, put another way, in pivotal cases where Court pronouncements are calculated to block new developments at the start before an administrative innovation can gather momentum in administrative practice. In terms of judicial behavior the Court's action seems to result not so much from a meeting of judicial minds on what the grand style would require, but from a coalition of judicial activists attempting to devise a politically correct ${ }^{47}$ solution to a real life problem and judicial passivists deflected from their deference to administrators by their desire to obey and enforce a command of Congress.

\section{RATEMAKING}

If we touch base with the traditional lore again, it might well be anticipated that even if the Supreme Court is provoked into activism by the certification conflict between railroads and trucks, it is surely deferent to the Commission on the highly technical and routinized question of rates. But if we distinguish such crucial policy problems as intermodal competitive rate cutting and revenue losses on commuter service from the traditional rate questions of evaluation, fair return, and tariff interpretation, a somewhat different picture emerges.

The Motor Carrier Act of 1935 and the National Transportation Policy of I940 were mainly "defensive" statutes designed to protect an ailing industry from ruinous internal competition. In the spirit of these statutes, and with the legal hook of the clause requiring the ICC to preserve the inherent advantages of each form of transportation, the Commission had traditionally weighted heavily the effect on competing modes of transportation when determining the reasonableness of rate cuts. Changed conditions in transportation had built up enough pressure by 1958 to cause Congress to introduce a new rule of ratemaking which was

46. See id. at $172 \& \mathrm{nn} .53,54$.

47. Unfortunately English does not provide an adverbial form of the noun "policy." By "politically correct" here I mean correct in terms of public policy. 
designed to nudge the Commission into a less noncompetitive attitude and presumably to allow the railroads to make better competitive use of their inherent cost advantage. The Supreme Court's Schaffer opinion, with its instruction to the Commission that the availability of a lower competitive rate be weighed as a favorable rather than an unfavorable factor in considering applications for certificates of convenience and necessity, seemed to be in line with Congress' new emphasis on competition. ${ }^{48}$

The congressional position, however, could be seen at best as the expression of a vaguely procompetitive sentiment and at worst as a meaningless verbal formula designed to relieve it of making a real decision on the question.

[T] he Commission, in determining whether a rate is lower than a reasonable minimum rate, shall consider the facts and circumstances attending the movement of the traffic by the carrier or carriers to which the rate is applicable. Rates of a carrier shall not be held up to a particular level to protect the traffic of any other mode of transportation, giving due consideration to the objectives of the national transportation policy .... 40

This is certainly broad statutory language inviting the administrative lawmaking of which Justice Frankfurter spoke in his Schaffer dissent, defending the widest discretion for the Commission. ${ }^{50}$ Nevertheless, the statute also seems to indicate congressional disapproval of the Commission's past practice, thus removing the protection of the longstanding practice doctrine and inviting Court intervention. ${ }^{51}$ The questions involved in such rate cases are not highly technical or long settled ones of cost accounting or evaluation. Instead, the basic issues are either broad ones of national policy or lesser ones of politico-economic prudence rather than exact calculation. The presence of a congressional command, but one not so clear or specific as to enforce Commission compliance, sets the stage for the intervention of the Court as guardian of the legislative will against administrative intransigence. I am not suggesting, however, that the ICC is necessarily intransigent, but only that any policy it chooses might appear violative of the intentions of Congress, given the vagueness of the statutory language.

The Court made a major pronouncement on the new rate provisions in ICC $v$. New York, N.H. \& H.R.R. ${ }^{52}$ In that case the New Haven sought to lower its piggyback rates to compete with Seatrain Lines, which hauled loaded truck trailers by sea along the Atlantic Coast. ${ }^{53}$ The ICC refused the reduction, apparently

48. See text accompanying notes $41-45$ supra.

49. Interstate Commerce Act $\$ 15 a(3)$, added by 72 Stat. 572 (1958), 49 U.S.C. $\$ 15 a(3)$ (1964).

50. 355 U.S. $83,93(1957)$.

51. See Shapiro, Lnw and Politics in the Supreare Court 154-55 (1964).

52. 372 U.S. 744 (1963).

53. It is peculiar that the first piggyback case to reach the Court was not a truck versus rail dispute, but in effect one between two piggybackers. In view of the continued litigational battle against piggybacking, which has in recent years concentrated not on the form itself but on the rates proposed, we can expect rail versus truck cases to reach the Court eventually. There has been a good deal of Commission action and some lower court action on Plan III piggybacking, to which there is likely to be greater opposition than there is to the other plans, particularly from labor. See 77th Annual Report of the 1.C.C., 31 ICC Prac. J. 391, 404-05, 411-12 (1964). In a recent case the Court over ICC opposition approved railroad rates devised to allow conventional rail service to compete with Plan III operations. See All States Freight, Inc. v. New York, N.H. \& H.R.R., 379 U.S. 343 (1964). 
applying its traditional "umbrella ratemaking" approach to protect an existing carrier from competitive forays in spite of the language of the I958 Act. The Commission chose to use two of the three escape clauses provided by the reference in that act to the National Transportation Policy. The National Transportation Policy calls for the preservation of the inherent advantages of competing modes, the prevention of destructive competition, and the preservation of a transportation system adequate to meet the needs of national defense. ${ }^{54}$ The Commission held that the New Haven's rates constituted destructive competition and a threat to the continued existence of the coast line shipping industry necessary to national defense. The Commission, however, found it impossible to determine which mode of shipping had an inherent advantage. Nevertheless, it found the proposed rate compensatory-that is, above out-of-pocket costs-and indeed suggested that it would accept lower rates as long as a differential above water rates was maintained. Quite clearly the rates were thus "held up to a particular level to protect the traffic of ... [another] mode of transportation."

The Supreme Court, however, in effect limited the reference to the National Transportation Policy in the $195^{8}$ Act to the one factor of inherent advantage. The national defense requirement was to be considered only under "extraordinary circumstances." Rate competition was not to be blocked unless it prevented the exercise of inherent advantage. ${ }^{55}$ The Commission's position was that the rate in question would be the first step in a railroad campaign against coastal shipping and that its decision was based on the predicted long term effects on national defense of this anticipated campaign. But the Court stated that the national defense provision would apply only when "the proposed rates in themselves genuinely threaten the continued existence of a transportation service that is uniquely capable of filling a transcendent national defense . . need."56 Furthermore, the fact situation-a rail and a water carrier each carrying truck trailers of totally heterogeneous cargo-seems to have been devised by the most fiendish legal muses to complicate the question of inherent advantage. At this point Justice Harlan modestly turned the case back to the Commission for further findings.

In order to maintain its rate protection for water carriers, the Commission was thus put in the position of having to find either that the particular rate in question would drive Seatrain out of business now or that Seatrain had an inherent advantage. Since it had acknowledged the first time around that it could not make either of these findings, the modest remand of Justice Harlan carried a hefty and not particularly well-padded punch of judicial activism in support of a policy of competition. Here again the unanimous decision was the result of an alliance of the modest bent on preserving "true" congressional policy and activists pursuing their own economic views.

It should be added, however, that the district court in this case had embarked

54. Act of Sept. '18, 1940, ch. 722, tit. I, $\$ 1,54$ Stat. 899.

55. Presumably where intermodal rates are concerned, even destructive competition per se is not enough to block lower rates. Many instances might arise in which the carrier with inherent advantage would, under true rate competition, drive the other carrier out of business.

56. 372 U.S. at 762 . 
on a quite detailed economic analysis culminating in a set of ground rules for the ICC on how to determine the interaction of inherent advantage and competitive rates. ${ }^{57}$ The Supreme Court totally ignored the district court's efforts and invoked the primary jurisdiction doctrine to allow the ICC to work out its own notions of inherent advantage. Thus policy initiative still rests with the ICC. The Court's invocation of the primary jurisdiction doctrine was not, however, necessarily a surrender of its policymaking powers. It is more likely to mean that the Commission will be allowed to initiate policies which will then be reviewed by the Court, and will be allowed to find inherent advantage in particular fact situations under general rules either devised or ratified by the Court. ${ }^{58}$

The great Mechling Barge war showed, however, that the Commission cannot push the Court too far, primary jurisdiction notwithstanding. A substantial amount of grain flows from northern Illinois into Chicago on the Illinois River and the rail lines that parallel it for eventual shipment eastward by rail. The Mechling Barge Line for many years has hauled some of this grain at a rate lower than that of the railroads. Certainly, grain is a cargo ideally suited to bring out any inherent economic advantages that water transportation might have. Nevertheless, the railroads, which depend heavily on grain carriage, have repeatedly made efforts to equalize water and rail rates.

These efforts first reached the Supreme Court in I947 in ICC v. Mechling Barge Lines. ${ }^{59}$ The ICC had permitted the railroads running eastward out of Chicago to charge a higher rate for grain that had reached Chicago by barge than for that coming in by rail. The effect of the differential rate east of Chicago was to offset almost exactly the lower barge rates west of Chicago, thereby equalizing barge and rail rates for the through shipper. The Supreme Court balked at this end run and instructed the ICC that the eastern roads might have only such higher rates on barge-carried grain as could be justified by higher transit costs. ${ }^{60}$

The ICC and the railroads later tried a new tack, the roads offering a through rate from the canal area to the east which was competitive with that charged by the barge-rail combination. In order to set such a rate, however, the roads had to violate the statutory prohibition against imposing lower rates for a long haul than for a short haul. ${ }^{61}$ The Commission might under certain circumstances allow exemptions. Justice Clark's dissent in the second Mechling case ${ }^{62}$ describes the Commission's practice:

The continuing practice of which the appellants complain consists of an application by the railroads for an order permitting the imposition of a lower tariff for

57. Perhaps the most daring feature of the district court effort was its attempt to substitute an incremental for a value-of-service basis of calculating rates.

58. The Commission appears to be giving some weight to the New Haven decision. See Garden Hose \& Elec. Cable From N.J. or R.I. to Tex., 319 I.C.C. 227 (1963); Sugar, South to Ind., Ohio River, Intermediate Points, 319 I.C.C. 782 (1963); Alcoholic Liquors From N.H. to N.Y. to Tex. \& La., 319 I.C.C. 396 (1964); Cereal, Coffee, Tea, Drugs, Related Articles, N.J. \& Pa. to Tex., 319 I.C.C. 424 (1964).

59. 330 U.S. 567 (1947).

60. This cost differential would be minimal; much of both the barge- and rail-carried grain is milled or otherwise processed in Chicago so that the eastern road faces the same physical loading situation whether the grain comes to the processing plant in barges or freight cars.

61. Interstate Commerce Act $\$ 4(1), 24$ Stat. 380 (1887), as amended, 49 U.S.C. $\$ 4(1)$ (1964).

62. A. L. Mechling Barge Lines v. United States, 368 U.S. 324 (1961). 
a long haul than is charged for a short haul over the same line; the issuance by the Commission of a temporary order without the necessary findings required by Sec. 4(I); the maintenance of such temporary order as long as possible by delaying the final disposition of the application; and the withdrawal or vacation of such order whenever a judicial test of its validity appears imminent, thereby frustrating any review on the ground of mootness. It is claimed that by continually repeating this process the railroads and the Commission have kept in effect an illegal tariff for transportation by rail to the damage of the competing barge lines. ${ }^{e 3}$

Indeed it was precisely on the question of mootness that the majority decision turned. This was a 5-to-4 decision, with the deferent taking the side of the Commission, the activists opposed, and the swing Justices, Clark and Brennan, split. Brennan's alliance with the deferent gave them the majority, and he wrote the opinion. If indeed the Commission was carrying on the bad faith maneuvering that the barge line alleged, the majority position is hardly compatible with the most elementary requirements of administrative justice. But this Mechling case was only a preliminary for Mechling number three, which reached the Court in $1964^{\circ *}$

The railroads came up with a new twist in their rate structure, the complexities of which need not concern us here. It again violated the long-haul, short-haul provisions of section 4 of the Interstate Commerce Act, thus requiring an ICC order allowing an exception. The examiner found against the railroads because part of the new rate failed to meet out-of-pocket costs and was lower than necessary to meet barge competition. The Commission, by following every twist and turn of the railroad's tortured logic of rate construction, was able to reverse its examiner and issue the exemption. The Commission's position was that while the rate in the western area in which there was direct competition with barges ("the proportional rate") might not meet costs, the through rate to the east considered as a whole was compensatory. It can be clearly seen from the opinion of the Court that at least some of the Justices found the Commission's maneuver highly distasteful..$^{65}$ But here apparently judicial caution about the technicalities of ratemaking came into play. The Court did not challenge the Commission's dubious rate logic directly but found another ground for reversal.

At the time of the ICC hearings the Chicago Board of Trade intervened to argue that the rail rates violated not only section 4 but also section $3(\mathrm{r})$ because they discriminated against Chicago grain merchants. ${ }^{66}$ In addition, Mechling itself argued that the rate violated the National Transportation Policy provision that the inherent advantages of each mode of transportation be preserved-a provision likely to be particularly embarrassing to a Commission striving to take high-bulk, low-value freight from a barge line and give it to a railroad. The Commission has long refused to issue section 4 exemptions if they would result

63. Id. at 333-34.

64. A. L. Mechling Barge Lines v. United States, 376 U.S. 375 (1964).

65. See text accompanying note 69 infra.

66. Section 3(1) provides: "It shall be unlawful for any common carrier subject to the provisions of this chapter . . . to subject any particular person, company, firm, corporation, association, locality, port ... to any undue or unreasonable prejudice or disadvantage in any respect whatsoever . . . " Interstate Commerce Act $\$ 3(1), 24$ Stat. 380 (1887), as amended, 49 U.S.C. $\$ 3(1)$ (1964). 
in violations of other sections of the transportation acts. ${ }^{67}$ Nevertheless, the Commission found the Board of Trade's allegations of violation of section 3(I) too remote to consider in the section 4 proceedings, largely by breaking up into little pieces a rate scheme whose total effect was discriminatory and then arranging the pieces in whatever artificial pattern suited its decision. Moreover, the Commission found that the part of the total rate it chose to consider did not constitute destructive competition, thus avoiding consideration of the National Transportation Policy. The Commission in effect told Mechling and others that if they wished to challenge the rates on grounds other than section 4 , they would have to initiate still further administrative proceedings.

The Supreme Court, speaking through Justice Clark, who had written the dissent in Mechling number two, proceeded to read the Commission a lesson on administrative fair play.

If the proceeding is splintered, contestants will be obliged to await the conclusion of $\S 4$ proceedings before raising claims of violations under other sections of the Act. Not only would this be poor administration but it would result in manifest inequities and allow potential windfalls to some carriers.

Moreover, such splintering appears to be contrary to the consistent policy of the Commission in fourth-section proceedings. . . .

We do not say that such a rule of consolidation is an absolute. . . . However, in the instant case, we see no practical reason why the merits of the several contentions should not have been reached. To require the parties to begin anew and thus spawn several cases, all of which might have been easily disposed of in the $\$ 4$ proceedings, needlessly subjects appellants' claims to the rigors of circumlocution so deadly to effective administrative and judicial processes. This proceeding is now in its seventh year--during all of which period the rate under attack has been in force-and still, basic questions as to the validity of the rate have not been considered by the Commission. ${ }^{88}$

\section{The Court went on to the substance of the Commission's findings.}

The Examiner entered a finding, which is uncontested, that the proportional rate here under attack did not cover the out-of-pocket costs of the railroad. In spite of this finding, the Commission gave little, if any, consideration to any resulting violation of the National Transportation Policy. There is no economic analysis, no expert testimony, no supporting data. Instead, the Commission found that the through rate, which it thought compensatory, rather than the Belt Line proportional rate, was controlling. . . . The finding that the through rate was compensatory does not answer the question of whether the direct effect of the below-cost proportional rate on the Belt Line traffic is wholly at odds with the National Transportation Policy. Prior to the establishment of the rate, the barge lines enjoyed practically all of the traffic. However, the combination rate appears to have diverted appreciable traffic from the barge lines without any apparent profit to the railroad. ... We, therefore, do not believe it sufficient for the Commission to approve such a rate simply on a finding that the through rate is reasonably compensatory and no

67. See 376 U.S. at 383-84 and cases cited therein.

68. Id. at 383-86. 
lower than necessary to meet competition. In light of the facts present here, the claim of violation of the National Transportation Policy, raised and insisted upon by the appellants at all stages of the proceedings, must be specifically considered..$^{69}$

Although this was technically only a remand to the Commission for further proceedings, I have quoted this opinion at some length because the tone of the Court's language certainly indicates that it was after something more than sprucing up the niceties of Commission procedure and opinion writing. This decision was unanimous. It was on a rate question. This is hardly a Supreme Court which has abandoned ratemaking to the Commission. Even the most modest Justices apparently are not willing to allow the Commission a totally free hand. ${ }^{70}$

It may, of course, be argued that in fact the Commission has had its way in this case so far-no matter how deviously - and will probably continue to do so. But what seems most significant to me is that the Commission has felt it necessary to act in this rather curious way for so long in order to protect itself from Court intervention. It is not necessary for one government agency to evade another that would not have interfered anyway. At the moment we can surely say that the Court maintains enough presence in the rate area to cause the Commission to embark on elaborate strategic bypasses and maintains enough concern to chastise the Commission when its strategies become stratagems.

We have seen that where rate issues are really the focus of intermodal conflict, thus presenting the broadest questions of public policy, the Supreme Court does intervene. Other areas in which rates are closely tied to broad policy issues are the relation of inter- to intrastate rates and of freight to passenger rates. Initially the ICC required both freight and passenger services to pay their own way. The Commission has gradually changed that policy and frequently, as a matter of discretion, will consider freight and passenger rates together, contenting itself with a rate structure which is compensatory on an overall basis. The Supreme Court has approved the Commission's discretion in raising freight rates to counterbalance passenger losses. ${ }^{71}$ The relation of inter- to intrastate rates frequently arises in the context of a conflict between a state commission and the ICC over intrastate rates. The ICC has the power to eliminate discrimination against interstate commerce by adjusting intrastate rates when they do not provide their proportionate share of the railroad's total revenues. Naturally in many cases the state authorities are likely to come to somewhat different conclusions than the Commission.

In $195^{8}$ the Court used two such cases to initiate new policies on passenger carriage in general and commuters in particular. ${ }^{72}$ There is no need to go into the details because, as we shall soon see, the new policies were short-lived, but the cases do indicate a fair measure of judicial boldness on rate questions. To begin

69. Id. at 386-88.

70. The modest wing was probably pacified here by a decision which technically directs the Commission to make more findings rather than overturning the one it made, although the displeasure of the Court with the finding could hardly have been more clearly expressed.

71. See King v. United States, 344 U.S. 254 (1952).

72. Public Serv. Comm'n v. United States, 356 U.S. 421 (1958); Chicago, M., St. P. \&: Pac. R.R. v. Illinois, 355 U.S. 300 (1958). 
with, the Court had to do considerable pulling and hauling to make its new decisions square with precedent. ${ }^{73}$ The decisions also severely limited the previous discretion of the Commission on rate questions. The thrust of the opinions was that before the Commission could grant a rate increase on any given intrastate passenger line, it would have to show that the total combined intrastate passenger and freight revenues of the road in question did not meet its total out-of-pocket costs of intrastate operation. This, of course, was to require the Commission to do consistently what it previously had sometimes done at its own discretion, and thus marked a major turning point in the law in favor of state authorities attempting to preserve relatively low cost mass transportation systems.

The decision in the first of the two cases, Chicago, M., St.P. \& Pac. R.R. v. Illinois, was unanimous; indeed it is one of the two instances in which Frankfurter and Burton voted against the Commission and the only one in which they voted against the Commission when a clear government versus business, rather than business versus business, conflict was involved. It is the one case that breaks the clear pattern developed earlier in which no member of the modest wing had ever voted against the Commission except when the claims of two rival carriers were involved. When the case was initially decided, it was unclear whether it constituted a major policy intervention by the Court or a minor correction of ICC procedures in an unusual situation. ${ }^{4}$ When Public Serv. Comm'n made it clear that the Chicago R.R. case was intended to be read broadly, the pattern normally expected reappeared with Justices Frankfurter, Burton, Harlan, and Whittaker dissenting and Brennan and Clark providing the margin for an antirailroad result. Justice Frankfurter's dissent focused on the evils of hampering the ICC's nationwide responsibilities.

A third case in the same term, involving basically the same issues, confirms the split, for it shows the same 5-to-4 vote. In County of Marin v. United States ${ }^{75}$ the California Public Utilities Commission had refused the Greyhound Company fare increases for commuter service to and from San Francisco on the basis of Greyhound's overall profits on intrastate operation. Greyhound sought to evade this holding by transfering the commuter operations to Golden Gate Transit Co., thus isolating the commuter service from the rest of its intrastate business. The ICC approved this transfer under its authority to authorize mergers. The Supreme Court reversed the Commission, holding that the transaction was not a bona fide merger, but a splitting off of certain operations to a mere corporate shell. Obviously the five-man majority of the Public Serv. Comm'n case was bent on seeing that its policy was not evaded by artificial legal maneuvers.

Shortly after these three decisions Congress passed the Transportation Act of

73. See Public Serv. Comm'n v. United States, 356 U.S. 421, 429 (1958) (Frankfurter, J., dissenting).

74. The case might have been read to turn on the peculiar question of what range of evidence the Commission should take into account in constructing an intrastate rate when there is no comparable interstate rate on which to base its calculations. So read, the ICC's discretion is not limited, the Court only prescribing the range of relevant evidence to be considered when the Commission must make a totally de novo calculation.

75. 356 U.S. 412 (1958). On commuter abandonments see Illinois v. United States, 373 U.S. 378 (1963) (per curiam); New Jersey v. New York, S. \& W.R.R., 372 U.S. 1 (1963). 
$1958,{ }^{76}$ which in effect reversed them and returned to the ICC the discretionary power to focus on whatever segment of intrastate traffic seems most relevant to it. All that remains of this judicial foray into ratemaking, therefore, is the requirement that the Commission present substantial evidence to support a finding that intrastate and interstate conditions are not sufficiently different to warrant the lower rates approved by the state. Of course, it is quite routine for Congress to alter judicially initiated policies. This very routine is interesting here, however, for it again shows the Court participating with the Commission, Congress, and the interests affected in making and changing rate policies.

The Court subsequently had an opportunity to review the new congressional policy in Southern Ry. v. North Carolina ${ }^{77}$ a case involving abandonment of intrastate passenger trains under the I958 Act. Technically this was not a rate case, but it raised the same question of how broad a base to choose in determining whether intrastate service creates a revenue drain on interstate carriers. The district court found that since the congressional language reversing Public Serv. Comm' $n$ had been inserted only in the rate provisions of the $195^{8}$ Act, the abandonment provisions were still governed by the doctrine in that case. The district court held that in determining whether to allow abandonment of a passenger train along one line, the Commission should consider whether that line was paying its own way on the basis of total combined passenger and freight revenues.

Seven Justices of the Supreme Court were unwilling to ignore clear indications of congressional intentions. They candidly admitted that Congress had reversed the Court's earlier policy. Indeed they found in the legislative history the suggestion that the Commission ought to let freight and passenger service stand on their own when determining whether rates are compensatory. But what they did not do was gracefully resign from this policymaking sphere. Instead the Court reviewed the findings of the Commission and found that the relatively minor public need for rail passenger service in this instance, combined with the relatively high losses suffered by the particular service to be abandoned, justified the Commission's decision to permit abandonment.

Then the Court replied to Justice Goldberg's dissenting complaint (joined by Chief Justice Warren) that, in allowing the Commission to consider solely the profit and loss on a particular passenger service, the majority was authorizing abandonment of all commuter service since all of it lost money.

"In some cases . . . the question is whether abandonment may justly be permitted, in view of the fact that it would subject the communities directly affected to serious injury while continued operation would impose a relatively light burden upon a prosperous carrier." In cases falling within the latter category, such as those involving vital commuter services in large metropolitan areas where the demands of public convenience and necessity are large, it is of course obvious that the Commission would err if it did not give great weight to the ability of the carrier to absorb even large deficits resulting from such services. But where, as here, the Commission's findings make clear that the demands of public convenience and necessity are

76. Pub. L. No. 625, 72 Stat. 568 (1958) (codified in scattered sections of 49 U.S.C.).

77. 376 U.S. 93 (1964). 
slight . . . it is equally proper for the Commission, in determining the existence of the burden on interstate commerce, to give little weight to the factor of the carrier's overall prosperity. ${ }^{78}$

Thus, while accepting congressional correction with good grace, the Court unanimously insisted that it will maintain supervision over abandonments of passenger service to protect the public interest in commuter mass transportation. The whole tone of the opinion suggests that the Court will treat future cases on their merits, balancing public need against revenue loss. Of course, the Harlan wing probably would employ the substantial evidence rule to defer to Commission findings, but it is equally clear that the language of Southern Ry. contemplates future Court intervention. Presumably we can look forward to continued Commission-Court-Congress interaction on the commuter question.

One of the Court's most recent ICC decisions, All States Freight, Inc. v. New York, N.H. \& H.R.R., ${ }^{79}$ dramatically illustrates its continued concern for the most important problems of rate policy. Several of the competitors of the New Haven had introduced piggyback service resulting in an immediate and alarming impact on New Haven car loadings. At the time, the New Haven was unable to introduce a similar service because of overhead clearance problems along its line. It countered by a new, low, all-commodity rate competitive with the piggyback rates.

There are two basic kinds of rates. The railroads have traditionally set class rates, consisting of a series of classes, each at a different rate, with each item of freight classified as belonging to a particular class. The alternative is a series of commodity rates in which the item of freight is assigned a rate without regard to the class into which it would otherwise fall. Commodity rates are usually special adjustments to class rates to give the railroads flexibility in meeting local, nonrailroad competition on a particular item or in passing on the savings involved in handling large steady flows of a single commodity, such as coal from the pit head.

An "all-commodity rate" falls somewhere in between these two rate systems. It is officially a commodity rate, but it applies to more than one commodity. ${ }^{80} \mathrm{It}$ also is typically a minor exception to the basic class rates due to some peculiar traffic situation. Nonetheless, the New Haven's rate shows that when an all-commodity rate embraces a sufficient number of commodities, it becomes a general replacement for the class rate structure.

All of this is not a scholastic debate over what names a rate carries or what kind of rate table looks best. Class rates are based on the value-of-service concept. The more valuable the freight, the higher the rate, even though it may cost the railroad no more to haul diamonds than turnips. Since commodity rates were originally introduced to meet exceptional conditions, they are calculated ad hoc without necessarily taking account of value of service. Thus the all-commodity

78. Id. at 105. Quoting from Colorado v. United States, 271 U.S. 153, 168-69 (1926).

79. 379 U.S. 343 (1964).

80. "All-commodity" is something of a misnomer. In fact there are usually long lists of commodity exceptions published as part of such rates, and it might aptly be called a "some-commodity rate." 
rate can become a means of setting up a general rate structure that ignores the value-of-service concept. A dispute over class versus commodity rates may be, and was in All States Freight, really a dispute about the value-of-service principle in ratemaking.

Technically, however, the question before the Commission and the Court was whether section I(6) of the Interstate Commerce Act ${ }^{81}$ applied to commodity or only to class rates. A majority of the Commission wished to use section I(6) to insure that the railroads would not circumvent the value-of-service principle by inflating commodity exceptions to class rates into an all-commodity rate system that would in effect replace the general structure of class rates. The Commission dissenters felt that the value-of-service principle, while suited to the earlier time when it was written into the statutes and when the railroads enjoyed a near monopoly, now hampered the roads in their attempt to compete successfully with motor carriers. In the hands of the railroads and a sympathetic Commission, and unencumbered by section $x(6)$, the all-commodity rate system could change the basic rate structure of the industry. The wording of the statute left ample room for this kind of administrative and judicial lawmaking.

Indeed All States Freight became the focus of conflict precisely because an all-commodity rate was used to lower rates well below the class rate structure in order to compete flexibly with those technological innovations that had destroyed the railroads' monopoly. The conflict arose over section $I(6)$ because these lower rates were still compensatory, making it difficult to rule them unreasonable on any grounds other than that section. The majority of the Commission, bent on preserving value of service, found that section I(6) applied.

There are actually two major issues here. One is the value-of-service concept itself, which in turn involves not only the rival interests of rail and motor carriers but also the rival interests of various shippers under a system in which the high value freight subsidizes the low. The difficulty, however, is not solely one of conflicting interests, but of genuine uncertainty about whether the economic position of the railroads would be improved by abandonment of value-of-service rates. The second major issue is one that arises repeatedly in rail versus motor regulation-should the ICC maintain policies underlying obsolete statutory provisions pending new congressional action or should it take its very existence and administrative competence as a mandate from Congress to adapt regulatory law to changing business conditions? In short, some of the commissioners may have found section $I(6)$ applicable because they felt that value of service was economically desirable, and others because they felt value of service was what Congress intended. The dissenters specifically said that value of service was unsound economically and that the Commission might legitimately change regulatory policy to meet new situations without awaiting new legislation.

The section I(6) issue that reached the Supreme Court did not directly raise the question of value of service. The peculiarly tangled set of considerations

81. Added by 36 Stat. 544 (1910), as amended, 49 U.S.C. $\$ 1(6)$ (1964): "It is made the duty of all common carriers subject to the provisions of this chapter to establish, observe, and enforce just and reasonable classifications of property for transportation, with reference to which rates, tariffs, regulations, or practices are or may be made or prescribed . . . " 
underlying the superficially simple question of whether Congress intended section I (6) to apply to commodity rates is indicated, however, by the peculiar voting alignment of the Justices. This was a 5-to-4 decision in an area where unanimous and near unanimous opinions are quite common. Moreover, the majority, reversing the Commission and holding section $I(6)$ nonapplicable to commodity rates, was composed of Justices Stewart, Harlan, Clark, Douglas, and Goldberg, with Justices Warren, Black, Brennan, and White joining in a dissent stressing the need for judicial modesty. Justices Clark and Brennan split, as one might expect swing Justices to do in a case where it is difficult to determine what the economic effects of a decision either way would be. Justice Douglas, as usual, voted against the Commission.

The first difficulty arises from the votes of Justices Harlan and Stewart, who might seem doubly immodest in both reversing an administrative agency and doing so when it was attempting to act modestly vis-à-vis Congress. But the Commission itself committed one fatally immodest error. For many years it had ruled that section I (6) was not applicable to commodity rates. In the New Haven case it sought to break with this longstanding practice. Administrative agencies cannot expect those Justices who bolster their modesty with the longstanding practice doctrine to allow the agencies to suddenly contradict such practices. ${ }^{82}$ It is this facet of the politics of Court-agency relations that makes Harlan, Stewart, and Douglas bedfellows in this decision.

What is somewhat surprising, however, is to find Justices Warren and Black on one side and Justice Douglas on the other. It is possible that Douglas was less concerned with the substantive economic issues than with chastising the Commission for its improprieties. Warren and Black, focusing on those economic issues, were expressing the antirailroad attitudes that are to be found to a considerable degree in their voting in this area. Here, as in a number of other cases, they seemed to be maintaining an outdated vision of the railroads as a great economic power which must be restrained from throwing its full economic weight at its smaller competitors. At any rate, surely the substantive economic issues, and not the modesty professed in the opinion by Justice White in which they joined, accounted for their votes.

For my purposes, however, it is not the complexity of the issues or the tangled vote which makes this case particularly interesting, but the nature and setting of the decision. Here we find the Court again becoming involved in a piggybacking issue, one of the great new problems of transportation created by technological change. Here the Court is taking up probably the most crucial railroad rate policy problem, value-of-service ratemaking. And here the Court is actively involved in reversing a major rate policy decision of the ICC. I am not arguing that the Court provided a definitive solution to this basic problem of rate policy. Rather the Court in this case decisively blocked one attempt by the Commission to maintain the value-of-service principle against the various incursions to which it has lately been subjected. The Commission will undoubtedly make other attempts, and the dispute over value of service should continue for many years. Far from

82. See Shapiro, LAw And Politics in the Supreme Court 154-55 (1964). 
leaving ratemaking to the Commission, however, the Court has intervened to bolster the anti-value-of-service forces in their struggle to erode or bypass the traditional classification policies of the Commission.

The remainder of the rate cases decided by the Warren Court are more typical of the "routine" one would expect in this area. Generally, as soon as we leave those rate questions that involve major current issues of public policy such as intermodal competition and the commuter, the decisions reveal the degree of tentativeness and deference to the ICC that the traditional view would lead us to believe is uniformly found in all Court-Commission cases. ${ }^{83}$

\section{Motor Carrier Certificates-Of Grey Areas, Common Carriers, and Grandfather Clauses}

The ICC faces difficult problems in the area of motor carrier certification. The statutes contemplate three sorts of trucking operation: private, contract, and common carrier. ${ }^{84}$ Since each is subject to different regulations, drawing boundaries between the legislative categories seriously affects the economic interests of many firms, both carriers and shippers. The flexibility and variety of truck service constantly results in difficult to decide borderline cases and makes it relatively easy for carriers to find and exploit loopholes in the regulatory scheme. The basic problem is not one of mathematical calculation of cost allocation, but the more traditional one of deciding which of several alternative categories is appropriate in a particular fact situation. Given great incentive to litigate, a set of legal categories that blur into one another at the edges, and relatively simple but infinitely variable fact situations, we ought to expect a rather high level of judicial intervention. That is precisely what we find.

\section{A. Grey Area Problems}

The most crucial point of concern for the ICC within the general area of motor carrier certification is what has come to be called the grey area problem.

83. See H. K. Porter Co. v. Central Vt. Ry., 366 U.S. 272 (1961) (ICC can control discriminatory rates involving international commerce); United States v. ICC, 352 U.S. 158 (1956) (Commission can deny Government special tariff exemption not allowed private shippers); United States v. Chesapeake \& O. Ry., 352 U.S. 77 (1956) (whether napalm shipment should be charged "bomb" tariff involves technical questions of risk and special handling peculiarly appropriate for ICC); United States v. Western Pac. R.R., 352 U.S. 59 (1956) (same). For three typically "routine" tariff cases see Southwestern Sugar \& Molasses Co. v. River Terminals Corp., 360 U.S. 411 (1959); Boston \& Me. R.R. v. United States, 358 U.S. 68 (1958); ICC v. Baltimore \& O.R.R., 355 U.S. 175 (1957). On questions of rate preference and prejudicial rates the Court has in recent years been mute, although some of its earlier decisions at least formally govern the Commission. Major questions of policy are, however, building up steadily here. See Shinn, Freight Rate Prejudice and Preference, 31 ICC PRAC. J. 531 (1964). In Baltimore \& O.R.R. v. Boston \& Me. R.R., 373 U.S. 372 (1963), the Court affirmed a district court order reversing the policy of the ICC and requiring the equalization of most import-export rail rates between the "differential territory" and the "northern tier" of ports. But the affirmance was the result of an evenly divided vote, Justice White not participating, and, as is the custom in such instances, no opinions were issued. It appears then that Supreme Court silence in this important rate area is the result not of a general deference toward the Commission on rates, but of an even division in the Court between those who wish to be deferent and those who do not on the question of geographic differentials.

84. See Interstate Commerce Act $\$ 203$ (a) (15), added by 49 Stat. 544 (1935), as amended, 49 U.S.C. $\$ 303(a)(15)$ (1964). In addition to the cases discussed below, the reader should note that just before the period being examined here the Court made a general pronouncement defining the contract carrier category in United States v. Contract Steel Carriers, Inc., 350 U.S. 409 (1956). 
When a firm primarily engaged in a business other than transportation operates its own trucks in pursuit of its primary business, it is a private carrier-for instance, a meat packer who distributes his own dressed beef. Private carriers are not regulated by the ICC. On the other hand, someone primarily in the transportation business who provides specialized trucking services for a given firm is a contract carrier - for instance, the owner of a fleet of refrigerated trucks who delivers dressed beef for a meat packer. Contract carriers must obtain an ICC certificate of convenience and necessity, which entails both an ICC determination that existing common and/or contract carrier service is not adequate and an ICC regulation of the rates to be charged. Private carrier status is, therefore, desirable, and two statutory loopholes have been exploited to obtain it. First, firms may provide all the trucking services normally performed by a contract carrier but do so under the form of truck leasing agreements rather than transportation service contracts. Under such leasing agreements it is technically the nontransportation firm which does its own hauling, having only leased some equipment from the trucking firm. Secondly, truck operators may enter buy-and-sell arrangements. The trucker buys his cargo at the point of pickup and sells it at its destination for a profit equivalent to transportation charges. In the process he becomes primarily a wholesaler who happens to ship the goods he owns in his own truck. Neither of these practices can be clearly distinguished from normal business operations. Leasing rather than buying expensive equipment like trucks has become a routine and legitimate part of many business operations, and many wholesalers engaged in legitimate buying and selling for a profit use their own trucks as an integral part of performing their middleman service.

\section{Leasing arrangements.}

The Supreme Court has made leading policy pronouncements on both loopholes. Leasing arrangements reached the Court in United States v. Drum. ${ }^{85}$ The appellee, an Oklahoma furniture manufacturing company, had for many years hauled its own product in its own tractor-trailer rigs and thus enjoyed private carrier status. In $195^{2}$ the firm introduced a system under which its drivers held title to their tractors, but the company maintained direction of all time schedules and routing, serviced and insured the vehicles, and paid the drivers salaries and lease fees for use of their tractors.

The ICC investigated the furniture company's operations on its own initiative and ruled that under the new arrangements the drivers were contract carriers requiring certificates of convenience and necessity. The ICC's finding was part of a typical campaign of administrative lawmaking. The Commission had initially used a "primary business" test for differentiating private from contract carriers. ${ }^{86}$ This test had been approved first by the Supreme Court and then by

85. 368 U.S. 370 (1962).

86. See Lenoir Chair Co. Contract Application, 51 M.C.C. 65 (1949), aff'd per curiam sub nom. Brooks Transp. Co. v. United States, 340 U.S. 925 (1951); L. A. Woitishek Common Carrier Application, 42 M.C.C. 193 (1943); Congoleum-Nairn, Inc., Contract Carrier Application, 2 M.C.C. 237 (1937); Lyle H. Carpenter Common Carrier Application, 2 M.C.C. 85 (1937). 
Congress. ${ }^{87}$ As various modes of evasion popped up, the Commission introduced a "control" test that cut through the legal technicalities to determine whether the shipping involved was functionally controlled by the shipper or by an independent trucker. This "control, direct and dominate" test was again evaded by truck firms, which reorganized themselves as lessors whose vehicle operations were "controlled" by the various firms to whom they leased. Obviously, the distinction between a shipper who leases from a trucking firm and then controls the routing of the trucks and one who contracts for service with the same firm specifying where and when he desires service is likely to be a distinction without a real difference. Yet this arrangement seemed to undercut the control test, probably because the Commission had been fairly specific about what constituted control, and the truckers had therefore found it relatively easy to devise lease arrangements to avoid its criteria. The Commission then began questioning whether the truck operation was "in substance" private or contract, "substance" being the vaguest possible limitation on the Commission's discretion to foil the truckers' evasive tactics.

Drum came at the transitional stage from "control" to "substance" and was the first case in which the substance test reached the Supreme Court. The Commission rested its decision on both the control and substance tests. It is, of course, a typical ploy of both administrative and judicial lawmaking to introduce a new test while maintaining the old and then gradually to rely more and more heavily on the new as the old is gradually eased out. The district court interfered with this process by holding that under any view of control the furniture company was still controlling its own shipping operations. The Commission thus lost the camouflage provided by the control test and had to go to the Supreme Court solely on the merits of the substance test.

The Commission maintained that the substance test was simply an emphasis on the functional aspects of control, citing frequent instances in which the district courts in applying the control test mentioned "substance." This was nothing more than word magic, as Drum itself illustrates. In using "substance" the district courts were stressing the functional rather than formal nature of the control test. What counted was who really controlled the shipping operation, not who legally controlled it. The Commission's substance test, on the other hand, was no more than a statement that the Commission ought to have wide discretion in determining who was a contract carrier. The test is "whether any person is engaged, in substance, in for-hire transportation." no connection with the question of functional control. There the Commission argued that in determining "the exclusive right to control ... little probative weight" was to be given to the fact that the company actually controlled its

87. Brooks Transp. Co. v. United States, 340 U.S. 925 (1951) (per curiam); Interstate Commerce Act $\$ 203$ (c), added by 71 Stat 411 (1957), as amended, 49 U.S.C. $\$ 303$ (c) (1964); S. REP. No. 1647,85 th Cong., 2d Sess. 5 (1958); H.R. REP. No. 1922, 85th Cong., 2d Sess. 18 (1958); 104 CoNG. REc. 10818 (1958); id. at 12535-36.

88. Oklahoma Furniture Mfg. Co.-Investigation of Operations, 79 M.C.C. 403, 412 (1959), order set aside stb nom. Drum v. United States, 193 F. Supp. 275 (1960), reversed, 368 U.S. 370 (1962). 
shipping. The substance test became the means of ignoring actual business practices and focusing on the legal formality of "the exclusive right to control." In other cases, of course, the test could be used to focus on function-which would then undoubtedly be called "substance, not form."

The Supreme Court backed the ICC, but it apparently wished to provide some level of Court supervision through concrete regulatory standards rather than to allow the Commission total discretion. Thus it injected a new "financial burden" standard into "substance" that, like the old functional control approach, would limit Commission discretion.

The financial burden test is part of a paradox which the Court created and then aggravated by its own decisions. The furniture company was obviously not exploiting a loophole in the existing state of the law by using a leasing agreement to disguise as private carriage what was essentially contract trucking. Indeed, quite the reverse was true. What was essentially private carriage began to look something like contract carriage because of a leasing agreement. Yet any rule of law that would have excluded the furniture company from ICC regulation would also have excluded trucking firms that were deliberately avoiding regulation through the formalities of lease agreement. One solution would have been to grant the ICC total discretion under its substance test to get the "bad guys" and leave the "good guys" alone. The Supreme Court, however, is usually reluctant to leave an administrative agency totally without standards; moreover, in this instance the Commission had regulated a "good guy," hardly an ideal setting in which to grant it freewheeling discretion. ${ }^{80}$

Furthermore, the Court was also unwilling to acknowledge that the furniture company's legitimate interests would have to be sacrificed in order to lay the legal groundwork for getting at those with illegitimate interests. It therefore sought some rationale by which to find that the furniture company had not met the existing legal criteria for private carriers. The company dispatched, insured, and maintained the trucks involved. They were operated exclusively at its discretion and carried only its own cargo. It was difficult under such circumstances to find any element of control by the truck owner. The Court, therefore, focused on the fact that the driver-owner took on some of the financial burdens of transportation, such as initial capital outlay and operating costs. The Court found this to be enough to constitute some level of control in substance of the trucking operation, thus providing a facade of continuity with the previously existing law.

The financial burden test is a concrete, court-controlled standard limiting the ICC's discretion. Nonetheless, in modifying the ICC's discretionary and precedent-breaking substance standard, the Court paradoxically has given the Commission far more regulatory scope than it asked for and amended existing legislation to a far greater degree than even the ICC had intended. The ICC had been attempting to regulate truck firms that "leased" rather than contracted

89. It was clear from the facts in Drum that the leasing arrangement was not used as a subterfuge to avoid the certificate requirement. Rather the arrangement was challenged because it was a type which could easily be used as a subterfuge by others. 
a full transportation service. The Commission apparently picked this furniture company to get at the single-truck owner-driver, who is simply the miniature version of the multiple-truck firm which leases its trucks and provides drivers and other services. Drum was the borderline case in which the truck owner received compensation for his equipment in the form of lease payments and for his labor services in the form of salary. Such an arrangement obviously could serve as a cover for contract carriage in which charges would be nominally split between equipment rental and salary. Until the Drum case, however, the ICC had evinced no desire to inquire any further into the true situation and had held that mere equipment rental did not constitute contract carriage. Yet the financial burden undertaken by a legitimate truck rental agency is precisely the initial capital outlay that, according to the Court in Drum, is enough to constitute control in substance. Thus the Court has apparently plugged the loopholes far more radically than the ICC had first intended and in a way that seems fundamentally at odds with the developing business practice of renting rather than owning high cost, high depreciation equipment. Since Drum the Commission is free to take the position that the shipper must shoulder the entire financial burden of operating his trucks and hiring the drivers in addition to maintaining both under his control.90

The Drum story is a rather typical one. The administrative agency attempts to plug statutory loopholes first by providing concrete standards and then by shifting to standards that permit broad powers of discretion. It runs into trouble with lower courts seeking to maintain the existing law developed under the original standards. The Supreme Court eventually intervenes to aid the agency, but insists upon providing its own standards within which the agency must operate, rather than giving it complete discretion. In this way the Justices retain control of supplementary lawmaking, even if it means only adopting the agency's standards as its own. Drum breaks from the typical, however, because the Court in formulating a concrete standard to limit agency discretion adopted one so radical that it gave the Commission even more regulatory power than it had sought and altered the statute more significantly than the agency had done initially.

The vote in this case was $7-$ to-2, with Justice Frankfurter in the majority and Justices Harlan and Whittaker dissenting. This lineup illustrates how the two faces of judicial modesty often conflict in the ICC cases. Frankfurter, apparently seeing a conflict between agency discretion and Court supervision, voted for the Commission. Harlan and Whittaker in their dissent emphasized the conflict between previous congressional enactment and administrative-cumjudicial amendment, and voted against the Commission. Unless the remainder of the Justices were victims of a combination of faulty legal reasoning and naive formalism, we must assume that they were deciding the case in the grand style

90. It is not yet clear whether a firm that rented its trucks but shouldered absolutely all operating expenditures might remain a private carrier, because Drtum is not clear as to whether a dash of operating cost burden must be added to the capital investment burden to constitute control in substance. There seems to be little doubt, however, that the ICC could push Drum to its logical extreme, although such action might inspire congressional reaction. 
on the basis of what they considered to be the best public policy. As a decision in the grand style, Drum seems faulty because it fails to appreciate both the broadest aspects of the situation - the legitimate movement toward major equipment rental - and the specifics of the actual situation-the real nature and intent of the company's leasing arrangements.

\section{Buy-and-sell arrangements.}

The second major problem, buy-and-sell operations, stems from the congressional adoption of the Commission's "primary business" test to plug loopholes in the private carrier provisions. ${ }^{91}$ Indeed the legislation is an instructive story of the interaction between courts, administrative agencies, and Congress. The Commission devised the "primary business" language because the language of the statute was not explicit enough to block many evasions. The Supreme Court approved the language in $195 \mathrm{x}^{.2}$ Subsequently the Fifth and Ninth Circuits attempted to undercut the test by requiring the Commission to make a positive showing of common or contract type carriage rather than the simpler negative showing that the carriage was not in furtherance of the shipper-carrier's primary business. ${ }^{93}$ The ICC, backed by the regulated portions of the trucking industry, worked from I953 until I957 to get the primary business language incorporated into the statute as section 203 (c). ${ }^{94}$

Having obtained a law to codify its past practice, the ICC then attempted to go beyond the new statute to firmly plug still another loophole. It argued that the new statute was intended by Congress to establish a per se rule against buyand-sell backhauling by firms admittedly undertaking private carriage on the outhaul. ${ }^{95}$ Private carriers are particularly tempted by buy-and-sell devices. Typically a manufacturer or jobber delivering merchandise from his own plant or source of supply to a buyer will have to backhaul empty with resulting increases in per unit costs of transportation, unless he can pick up some outside cargo for the return run. Such backhauling might be viewed as illicit contract or common carriage. On the other hand, such an interpretation of the statute might be viewed as extending the right of private carriage with one hand but depriving private carriage of its economic viability with the other. A firm cannot in practice exercise its private carrier rights if empty backhauls force its transportation costs up higher than those it could obtain from regulated carriers. It could also be argued, however, that the economic efficiency of full loads out and back is an inherent advantage of contract and common carriers. A sound economic policy would require firms to employ the services of regulated carriers rather than to continue an essentially uneconomic shipping operation by poaching on the business of the regulated carriers.

91. Interstate Commerce Act $\$ 203$ (a) (17), added by 49 Stat. 545 (1935), 49 U.S.C. $\S 303$ (a) (17) (1964).

92. See Brooks Transp. Co. v. United States, 340 U.S. 925 (1951) (per curiam).

93. Taylor v. ICC, 209 F.2d 353 (9th Cir. 1953); ICC v. Tank Car Oil Corp., 151 F.2d 834 (5th Cir. 1945).

94. Interstate Commerce Act $\$ 203$ (c), added by 71 Stat. 411 (1957), as amended, 49 U.S.C. $\S 303$ (c) (1964). The final version was based on a Transportation Association of America draft bill. Red Ball Motor Freight, Inc. v. Shannon, 377 U.S. 311, 315-16 (1964).

95. See Red Ball Motor Freight, Inc. v. Shannon, 377 U.S. 311, 316-17 (1964). 
Given the difficulty of the policy question, one would expect a Court genuinely concerned with policy to attempt to decide the individual case in a way that would allow flexibility in the future. And, indeed, in Red Ball Motor Freight, Inc. $v$. Shannon ${ }^{96}$ the Court seemed to be working in the grand style, although such a style here did not lead to legally neat results. The Court refused the Commission its per se rule and directed it to determine in each case whether the backhaul was being done by a bona fide noncarrier under the primary business test. This suggests that the crucial question is not whether the backhaul buy-and-sell arrangement is simply a screen for carrier service, but whether the firm doing the backhaul is, taken as a whole, a noncarrier. Presumably a bona fide noncarrier could engage in a purely carrier backhaul service under the guise of a buy-andsell arrangement if its outhaul were legitimately private. Moreover, the Court in this instance held that the firm was a bona fide noncarrier, and indicated that it intended to look behind Commission findings to the actual facts in future cases. The Court, however, went on to say that the ICC must determine on the facts whether a spurious buy-and-sell arrangement or a true wholesaling operation is being undertaken on the backhaul. ${ }^{97}$ This language suggests that the Commission should focus not on the general nature of the firm, but simply on whether a buy-and-sell arrangement has been concocted at any point, regardless of the rest of the firm's operations. In other words a firm, which by the primary business test is a noncarrier and whose outhaul is legitimately private, might still be violating the statute if its backhaul is really contract carriage disguised by a buy-and-sell arrangement.

Further confusing the issue is the statement:

The statutory scheme recognizes that mere availability and use of backhaul capacity may in particular cases be completely consistent with the bona fide conduct of a non-carrier business. Thus the question in this case is a narrow one: whether, applying the standards developed under the primary business test, appellees' backhauling of sugar was within the scope, and in furtherance, of a primary, non-carrier business. ${ }^{98}$

As I read this, the Court is saying the Commission must view the backhaul in the context of the firm's entire business operation, including its outhaul, to see whether the backhaul is an integral part of a primary noncarrier business. It is here that Justice White parted company with the majority. Viewing the backhaul in isolation, he found it to be purely a buy-and-sell arrangement.

Confining the case to its narrowest limits, the majority found noncarrier status where the commodity backhauled was one of the several products in which a multiproduct wholesaler dealt. Thus the decision does not establish any new rule of law or even any particular judicial attitude; the Court merely found that

96. 377 U.S. 311 (1964).

97. Obviously many legitimate wholesalers would buy at one point and sell at another using their own trucks. In such operations passing the goods through the wholesaler's own warehouse represents an economic inefficiency. Therefore, the more efficient the wholesaler, the more his operations might look like buy-and-sell arrangements. The crucial question of fact in each instance is whether the firm is performing the services and taking the risks of an independent wholesaler.

98. 377 U.S. at 318. 
a multiple-product wholesaler is entitled to arrange his business so as to clear an overall profit by taking a loss on some items in order to increase his profits on others. It is not clear whether the decision applies to the wholesaler of a single item who takes on a second for backhaul purposes. Nor can any clear conclusion be drawn from Red Ball as to the status of a manufacturer who does buy-and-sell backhaul business to cover part of the delivery costs of the item he manufactures.

The majority decision thus carefully avoided total commitment on a difficult question of public policy by a combination of vague guidelines and emphasis on particular facts. At the same time it prevented the ICC from adopting a rigid position which would have made the legal right of private carriage meaningless by preventing the opportunity of turning that right into economically feasible round trip operations. Red Ball set the stage for further negotiations among interest groups and government agencies through the normal channels of administrative hearing and persuasion, litigation, and legislation. The Court blocked the ICC's attempt to forestall such negotiations without itself anticipating the final adjustment of interests.

This was a 5-to-4 opinion, but none of the dissenters was willing to accept the ICC's per se rule, and only Justice White found that the backhaul was not bona fide private carriage. Justices Goldberg, Harlan, and Stewart wished to return the case to the lower courts and the Commission for further findings of fact. This is, of course, a typically modest solution. It is significant that here again, where the Commission was obviously attempting to push beyond the intentions of Congress, the modests' deference to administrators was considerably undermined.

The Warren Court has entered the grey area only in Drum and Red Ballon the basis of sheer volume, at least, not an impressive record. Nevertheless, these two interventions have decisively affected the power of the ICC over carriers. Drum has extended the regulatory power of the ICC to truck leasing, a new and rapidly developing segment of the industry. The decision, moreover, represents a major change in statutory policy which effectively amends the transportation statutes. Red Ball, on the other hand, seriously limits the Commission's regulatory power in the crucial area of buy-and-sell operations and at least partially blocks the Commission's long campaign against private carriage in the grey area. Here again the decision has the impact of a statutory change-albeit a vague one -and allows the Court to keep its hand actively in the field. Thus the two grey area cases represent major delineations of the ICC's regulatory power and a declaration by the Court that it intends to maintain a supervisory role over the Commission in this field.

\section{B. Contract Versus Common Carriers}

The second major conflict within the trucking industry is that between contract and common carriers. The Motor Carrier Act of 1935 did not expressly favor common carriers over contract carriers, but the ICC developed such a policy in the thirties. Destructive competition was then the principal target of 
the Commission and, due to ease of entry, contract carriage was the principal source of such competition. In effect the common carriers were the stable core of the industry and contract carriers were cut-rate interlopers. The Commission felt the statutes were designed to protect the common carrier, and generally would not issue a contract certificate if reasonably adequate common carriage was available. While the Commission often spoke in terms of potential damage to the existing common carriers, on occasion it refused contract certificates even when no common carrier would be affected.99

By the postwar period competitive conditions in the industry had changed, but the Commission continued its pro-common carrier policy. While this policy may have contained some anachronistic elements, it was still economically defensible. The necessity and convenience of an economically sound common carrier system was undeniable. Contract carriers always threaten such a system because they tend to skim off the cream of the traffic. The contract carrier can generally offer a somewhat lower rate to high revenue traffic than the common carrier because it need not offset losses on other less remunerative traffic as must the common carrier. This becomes a vicious circle in which the common carrier is left with an increasingly higher proportion of the unremunerative traffic and so must set higher rates, which the contract carrier can more easily undercut for the part of the traffic he desires. Nevertheless, the rigid and automatic policy of favoring the common carrier became in the forties and fifties not so much a method of throttling unfair competition as a general limitation on competition in favor of the status quo common carriers.

Shortly before the period under consideration the Supreme Court weakened the status quo by holding in United States v. Contract Steel Carriers, Inc. ${ }^{100}$ that once granted contract carrier status, a firm might extend the number of its contracts indefinitely without becoming a common carrier. This decision was designed to allow some of the larger contract carriers to expand their operations closer to common carrier proportions and thus to compete with existing common carriers that had been excessively protected by the ICC's reluctance to grant new common carrier certificates. The Commission's attempt to protect status quo common carriers thus led to a Court-created loophole in the statute that encouraged the growth of large, new trucking firms. These firms were in an even better competitive position vis-à-vis the old common carriers than they would have been if they had been granted common carrier status, since they could pick and choose their traffic.

The Commission immediately went to Congress to close this loophole and Congress replied with the 1957 amendments to sections 203(a) (I5) and 209(b) of the Interstate Commerce Act. The amendment to 209 (b) provided:

In determining whether issuance of a permit will be consistent with the public interest and the national transportation policy declared in this Act, the Commission shall consider the number of shippers to be served by the applicant, the nature of

99. See Willard J. Hibbard Extension of Operations-Lime, 47 M.C.C. 311 (1947); R. L. Smith Contract Carrier Application, 1 M.C.C. 717 (1937).

100. 350 U.S. 409 (1956) (per curiam). 
the service proposed, the effect which granting the permit would have upon the services of the protesting carriers and the effect which denying the permit would have upon the applicant and/or its shipper and the changing character of that shipper's requirements. ${ }^{102}$

The statute created further conflict between the Commission and the Court, for the Commission took the position that the statute not only closed the loophole but also codified its longstanding practice of refusing contract certificates unless no adequate common carrier service existed.

The Supreme Court rejected the Commission's position in ICC v. J-T Transp. $\mathrm{Co}^{102}$ In that case two contract carriers had sought extension of their certificates to cover new cargo items. In spite of the shippers' pleas that contract carriage better suited the needs of their businesses, the ICC maintained its traditional policy of refusing contract certificates where reasonably adequate common carriage existed. The Supreme Court held that the Commission had erred in considering only the adequacy of common carriage without also giving weight to the specific needs of the shippers. The Court admitted that the new statute had overthrown its decision in United States v. Contract Steel Carriers and thus had allowed the ICC to limit the total number of contracts held by a contract carrier. Nonetheless, the Court seized upon the "and/or its shipper" language of the statute, finding that Congress had also intended to reverse the Commission's longstanding policy and to require it to consider not only the interests of the common carriers but also the needs of the shippers.

This was less an inquiry into legislative intent than a resort to the plain-meaning canon of statutory interpretation, for it seems highly unlikely that either the Commission or the Congress realized that the inclusion of those few words would radically alter the Commission's policy. Indeed the result of this statutory interpretation depends entirely on the starting point. Starting with the plain meaning of the words, read literally and in isolation, the statute clearly reversed the old Commission practice. On the other hand, starting with Congress' general intent to aid the Commission in plugging loopholes in its certification practice, the specific wording arguably codified all the factors which the Commission had in the past been free to consider if it wanted to. ${ }^{103}$

This decision obviously rests on something analogous to what in the old days we would have called economic due process. This is especially true of the companion case of appellee Reddish, who had been denied a contract certification despite persuasive evidence that the common carrier rates were prohibitive. Even the modest wing could not bring itself to back the Commission in its denial of Reddish's certificate. The Court in effect reminded the Commission that it may not pursue its job of refereeing the competition between common and contract

101. 71 Stat. 411 (1957), 49 U.S.C. \$ 309(b) (1964). (Emphasis added.)

102. 368 U.S. 81 (1961).

103. It must be noted, however, that the Justice Department apparently felt the wording to be so clear that it refused to act for the Commission in this case. The Commission appears to have acquiesced and to be following the doctrines laid down in $1-T$ Transp. See Griffin Mobile Home Co. Contract Carrier Case Application, 91 M.C.C. 801 (1963); Moyer Contract Carrier Application, 88 M.C.C. 767 (1962). 
carriers by ignoring the interests of the shippers. In fact it criticized the Commission for presuming that new entries would adversely affect existing service and placing the difficult burden on the applicant of proving the inadequacies of existing service.

In what must be recognized as a recurrent phenomenon of judicial-administrative politics, the Court coupled its bold doctrinal pronouncement with a modest referral of factfinding and first determination back to the ICC. In the long run J-T Transp. may be more important for its caution to the district courts to return cases to the ICC for basic findings of fact than for its substantive law. Having dealt a severe blow to the ICC's policy by its legal pronouncement, the Court nevertheless left the Commission firmly in control of the fact-finding process; this control, of course, will allow the Commission to work toward its original goals through the subtleties of administrative decision making even though it has temporarily lost at the level of general statutory interpretation. Thus we find here the same politics of bargaining we find in the rest of government. One government body blocks a second which is assaulting the first body's policy views too quickly and too directly. But it does so in such a way as not totally to frustrate the second body, for such frustration might lead to even more vigorous direct assault. The Commission in this instance was left free to take maximum advantage of its factfinding powers, but with full knowledge that if it attempts to completely and rapidly overthrow the Court's policy stance, the Court is likely to intervene again.

$J-T$ Transp. in effect strengthens the hand of one of the participants in the bargaining sessions at ICC hearings. Any weight given to the shipper's interest as required by $J-T$ Transp. is likely to give considerable advantage to the contract carrier, because the basic advantage of contract carrier service is that it can be better tailored to shippers' needs than common carriage. Indeed in any given dispute between a common and contract carrier, counting the shipper's interest is actually counting the contract carrier's interest twice, for presumably the contract carrier would not be applying for extension if it did not have customers who preferred its services to those of a common carrier.

In Reddish's appeal, the contract carrier's interest was also furthered by the Court's holding that a lower rate offered by the prospective contract carrier must be considered as one element in the shipper's interest. We have already noted that because of its selective carriage a contract carrier can frequently undercut the rates of a common carrier. For this reason, the Commission had always refused to give weight to lower contract rates so long as reasonably adequate common carrier service was available, no matter how much higher the common carrier rates were. The Court directly reversed this policy. Thus the contract carrier now comes to the hearing room with a Supreme Court pronouncement in favor of shippers' needs to balance against the Commission preference for common carriage.

The I-T Transp. decision was 6-to-3. The modest wing predictably dissented, although Justice Whittaker went along with the majority. Justices Frankfurter, Harlan, and Stewart found their usual deference to agency expertise reinforced 
by congressional intent. The legislative history strongly supports their case that Congress had intended to reenact in the $195^{8}$ amendments the Commission's longstanding practice, and that, consequently, $J-T$ had no grounds for attacking the Commission's pro-common carrier policy. ${ }^{104}$

When I-T Transp. is read together with Drum, some hint of an overall Court policy emerges. The Commission has been attempting to solve grey area problems by putting the squeeze on private carriage and heavily favoring common over contract carriage. Its movement, therefore, has been uniformly away from those forms of transportation least regulated and best suited to the special needs of particular firms toward that form most regulated and least suited to the special needs of shippers. The Supreme Court has backed the Commission in the movement away from private carriage, but at the same time has moved in the opposite direction on the common versus contract carriage question, stressing the interests of shippers. Perhaps the Court is in effect saying that it will assist in limiting the poaching of semi- or pseudo-private carriers on contract or common carrier traffic, but it will protect the shipper's interest by insuring him the availability of contract carriage to meet his special needs. Indeed the incentive to take advantage of the loopholes of private carrier status to avoid both regulation and dependence on common carriers might be materially reduced by greater emphasis on meeting shippers' needs through contract carriage.

\section{Grandfather Clauses}

Cases arising under the grandfather clause of the I957 amendments to the Interstate Commerce Act further illustrate the Court's refusal to abandon the contract versus common carrier area. In $x 957$ the Commission persuaded Congress to enact a tighter definition of contract carriage as part of its campaign to maintain common carrier service against contract carrier incursions. ${ }^{105}$ The amendment overruled United States v. Contract Steel Carriers, Inc. ${ }^{106}$ which held that a certified contract carrier did not lose that status by engaging in indiscriminate widespread solicitation. The grandfather clause permitted existing contract carriers who could not meet the new requirement to be issued common carrier

104. In Reddish, the companion case to J-T Transp., Frankfurter, Harlan, and Stewart concurred in the result. There the ICC, in the spirit of its most extreme earlier decisions, refused to grant a contract certificate even though common carrier rates were so prohibitive that common carriers would not get the business even if it were denied to contract carriers. The problem of the modest wing was to support the Commission's position where it was advantageous to the common carrier, but to restrain the Commission from carrying its position to logical extremes where it hurt the shipper without helping the carrier. At this point even the modest found some use for the new language about shippers' needs. They argued that when, and presumably only when, the common carrier rate is prohibitive, the shipper can demonstrate a specific need that can be filled only by contract carriage. Thus the Commission's policy of ignoring rate differentials was modestly approved while at the same time some measure of common sense was introduced into its application.

105. Section 203(a) (15) of the Interstate Commerce Act now provides: "The term "contract carrier by motor vehicle' means any person which engages in transportation by motor vehicle of passengers or property in interstate or foreign commerce for compensation .. . under continuing contracts with one person or a limited number of persons either (a) for the furnishing of transportation services through the assignment of motor vehicles for a continuing period of time to the exclusive use of each person served or (b) for the furnishing of transportation services designed to meet the distinct need of cach individual customer." As amended, 71 Stat. 411 (1957), 49 U.S.C. $\$ 303$ (a) (15) (1964).

106. 350 U.S. 409 (1956) (per curiam). 
certificates limited to "the transportation . . . of the same commodities between the same points or within the same territory as authorized in the [old] permit."107

In United States v. J. B. Montgomery, Inc..$^{108}$ the Commission seized upon the new legislation, as it had done in the past, to impose even more severe limitations on contract carriers. The details are not particularly important for our purposes here. Suffice it to say that the new certificate issued to Montgomery imposed more severe limitations on service than did the old permit. A unanimous Court overturned the Commission on the ground that Congress had intended to leave the contract carriers in as good a position as they had previously enjoyed. Here again the dual quality of judicial modesty was apparent. The modest would not defer to the Commission in this instance because the Commission had gone beyond the command of Congress. It bears repeating that in the field of administrative regulation this task of confining agency action to its statutory limits arises so often that the voting behavior of the judicially modest can be predicted only by determining what interpretation the judge is likely to give a particular statute.

Two other certification cases ought to be briefly noted. In Andrew G. Nelson, Inc. v. United States ${ }^{109}$ a motor carrier's certificate under the grandfather clause authorized him to carry the "stock in trade of drug stores." The Court refused to interpret these words to mean "goods such as are sold in drug stores" and thus approved the Commission's refusal of permission to carry beer, wine, groceries, and auto batteries. The Court used the same general rule that it applies to tariff construction. Words are to be taken in their ordinary meaning in the absence of ambiguity or specialized usage. The Court's real position, however, seems to be that the grandfather clause was intended to protect the carrier in the status quo ante, not to allow him to expand the scope of his operations as circumstances changed. Certificates issued under grandfather clauses are not really authorizations to conduct certain future business not yet existent; they verbally describe what past business the carrier had actually been doing so as to allow him to continue doing it. In effect the Court in Nelson refused to rely on vague verbal description when it was perfectly clear what operations the certificate had been designed to protect.

Finally Burlington Truck Lines v. United States ${ }^{110}$ involved a new certificate granted in the context of a labor dispute. In effect the ICC chose to deal with an illegal secondary boycott by granting new certificates to the carrier under other names so that under the new names it could absorb the business it was losing because of the boycott. While the Court's opinion is carefully dressed in the language of the Administrative Procedures Act, its message is simply that the Commission should handle such illegal boycotts through the cease and desist orders it is empowered to issue rather than by introducing extraneous labor considerations into certification proceedings. While the ICC action in this instance was favorable to the injured party, it would have created a precedent under which

107. Interstate Commerce Act $\$ 212$ (c), added by 71 Stat. 411 (1957), 49 U.S.C. $\$ 312$ (c) (1964).

108. 376 U.S. 389 (1964).

109. 355 U.S. 554 (1958).

110. 371 U.S. 156 (1962). 
a firm subjected to an illegal strike or boycott could have been confronted with the certification of a new competitor on grounds that it was not providing adequate service. The Nelson decision was 8-to-I and Burlington, unanimous. Both seem to be grand style solutions to relatively uncomplicated problems. Typically, one was decided for the Commission, the other against. ${ }^{111}$

\section{MERGers}

The ICC has had a prolonged record of impotence in stimulating or directing railroad mergers. ${ }^{112}$ Although the Commission can exercise some influence through its ultimate veto powers, ${ }^{113}$ initiative has always remained with the corporate directorships, and railroad management has not been known for its innovative dash. Nonetheless, in reviewing those cases where the Commission has considered the validity of mergers, the Supreme Court has maintained an activist role. In Minneapolis \& St. L. Ry. v. United States ${ }^{114}$ the Court held that the public interest standard used by the Commission in approving mergers permitted a reduction in competition that would otherwise violate the Sherman Act. The opinion, however, strongly preserves the Court's claim to be final arbiter of the application of the Commission's public interest criterion. In holding that competition is at least a factor that must be considered in determining the public interest, the Court retains the option of holding in future cases that the Commission has not paid sufficient attention to effects on competition. ${ }^{115}$

In addition to rail mergers, motor mergers and other joint-control devices are now also of considerable concern to the ICC. The Supreme Court has decided only one case in this area, and it is hardly a momentous one. Here again, however, we find the pattern of an emerging policy area and an early Court declaration that it will maintain a supervisory presence in that area.

The ICC has had a longstanding practice of requiring common carriers seeking to operate jointly to seek its approval. To put teeth in this policy, the Commission began to disapprove merger applications where the carriers had previously operated under joint control without such approval. The Commission has been moving toward a per se rule, holding in one case that nonapproved

111. See also Willis Shaw Frozen Express, Inc. v. United States, 377 U.S. 159 (1964) (per curiam). The Commission bas lately dealt with a whole cluster of cases like Willis involving grandfather clauses for frozen food haulage. While the Willis decision delivers no clear message, it implies Court dissatisfaction with the Commission's narrow circumscribing of the frozen food grandfather clauses in the face of the tremendous proliferation of the kinds and quantities of frozen food cargoes.

112. See Latham, The Politics of Railroad Coordination 1933-1936 (1959).

113. Most recently, for instance, its veto of the Santa Fe-Western Pacific merger.

114. 361 U.S. 173 (1959). Alleghany Corp. v. Breswick \& Co., 353 U.S. 151 (1957), should be noted in connection with the merger problem. Here the Court leaned over backward to find in Alleghany's fight to take control of the New York Central elements that would bring the matter under ICC rather than SEC jurisdiction. The ICC has always attempted to maximize its jurisdiction vis-à-vis the SEC over merger and other transactions involving railroads. Here the Court was its ally. Justices Douglas, Warren, and Black dissented in part because the majority's decision assigning the matter to the ICC relieved Alleghany of the far more rigorous supervision of the SEC.

115. For three other cases indicating a mildly pro-merger policy see Brotherhood of Maintenance of Way Employes v. United States, 375 U.S. 216 (1963), affirming per curiam 211 F. Supp. 19 (1963); Chicago, M., St. P. \& Pac. R.R. v. United States, 366 U.S. 745 (1961); Brotherhood of Maintenance of Way Employes v. United States, 366 U.S. 169 (1961). 
joint control alone would bar Commission approval of a subsequent merger unless "it clearly appears that the public interest will be served best by such approval." $"$ This sort of saving clause seems necessary, for the statute requires the Commission to decide merger questions on the basis of public interest, not simply disobedience to Commission policies. In Gilbertville Trucking Co. v. United States $^{117}$ the merging lines argued that the Commission had adopted a totally per se approach and was refusing to approve mergers where previously unapproved joint control existed without even considering the public interest.

The Supreme Court strongly supported the Commission in a unanimous opinion, holding that there was sufficient evidence to justify the Commission's finding of previous joint control. The Court held further that the Commission did not invoke a per se rule and did consider the public interest. But the Court put the burden of proof of public interest so heavily on the joint-control truckers and used language that came so close to justifying a per se rule $e^{118}$ that the Commission was greatly bolstered in its movement toward such a rule.

Nevertheless, the opinion was far from a simple bow to the Commission. First, the Court's decision was obviously affected by the Justices' conclusion that in fact only the thinnest fiction of independent operation was maintained in the premerger operations by each of the two firms involved. Secondly, by stating that the Commission had acted properly in not invoking a per se rule, the Court effectively forbade it from invoking such a rule in the future. Thus, because the Commission will still be required to make at least a nominal determination of public interest, it will remain subject to Supreme Court supervision on this issue. In Gilbertville the Supreme Court in effect said to the Commission, you may routinely disapprove mergers involving previous, unapproved joint control, subject to our intervention in those instances where we feel public interest warrants approval. Finally, the Court reversed the Commission order of divestiture aimed at curing the joint control because the Commission had not fully considered alternative remedies. The Court cited the general rubric from antitrust law that divestiture is a drastic remedy to be used only as a last resort. Here again the Court reminded the Commission that it is subject to judicial supervision and must respect judicial policies.

\section{INTERSTATE COMMERCE}

Next we will look at those cases that scholars who take the traditional, constitutional law approach to the study of the Supreme Court would find of interest to the exclusion of all the nonconstitutional, but really important, cases we have examined so far-those obscure footnotes to Gibbons v. Ogden ${ }^{119}$ in which the constitutional lawyer delights but which mean relatively little to those interested in the politics of the Court. The story is briefly told. In H.K. Porter Co.v.

116. Central of Ga. Ry. Control, 307 I.C.C. 39, 43 (1958).

117. 371 U.S. 115 (1962).

118. Id. at $127-29$.

119. 22 U.S. (9 Wheat.) I (1824). 
Central Vt. $R y .{ }^{120}$ where a joint through rate was calculated from points in Canada, the Court held that the ICC had jurisdiction, since the American roads had sufficient control over the total rates to allow compliance with Commission rate orders. In City of Chicago v. Atchison, T. \& S.F.R.R. ${ }^{121}$ the firm that replaced the old Parmalee Company in the transfer of passengers and baggage between Chicago's railroad stations was held to fall under ICC jurisdiction, even though all of its operations were confined to one city.

Service Storage \& Transfer Co. v. Virginia ${ }^{122}$ is a somewhat more important case. Here a trucker carried freight between two points in Virginia, but hauled it by way of its terminal in West Virginia. Virginia considered this intrastate commerce and fined the carrier for violation of state regulations. The Supreme Court, relying on a Commission finding that the carrier's routing was a normal part of its operations rather than a subterfuge to avoid intrastate regulation, held the shipment to have been in interstate commerce. In the course of its opinion it also strengthened the ICC's jurisdiction. The Court held that to uphold the state in this instance would effect a partial suspension of the carrier's ICC certificate, and interpretation of such certificates should be made in the first instance by the Commission. Apparently the Commission is to act as initial referee of the interstate-intrastate boundary when its own certificates are involved. ${ }^{123}$

Finally, the Marin case, ${ }^{124}$ which we have already examined, involved the inter-versus intrastate issue and, unlike Service Storage and Chicago v. Santa Fe, was decided against Commission jurisdiction. But the real issues in that case had little to do with the traditional distinction and the holding on that issue is largely coincidental to the Court's principal concerns.

What is most interesting about this small and basically insignificant group of cases is its smallness and insignificance. Viewed through the spectacles of constitutional law, the work of the Warren Court in connection with the ICC would be largely reduced to this category, which is one of the least revealing of the links between the Court and the Commission. These cases may not teach us much about either the Warren Court or the ICC, but they tell us a great deal about avoiding artificial boundaries when seeking to discover the role and function of the Supreme Court.

\section{ICC Procedures ANd Remedies}

We turn finally to the cases which raise the least constitutional, most "narrowly technical," issues to confront the Warren Court in connection with the ICC and find that even here the Court has played an active role in policymaking.

120. 366 U.S. 272 (1961).

121. 357 U.S. 77 (1958).

122. 359 U.S. 171 (1959). See Arrow Carrier Corp. v. United States, 375 U.S. 452 (1964), affirming per curiam 219 F. Supp. 43 (D.N.J. 1963).

123. For other cases dealing with the intra-interstate issue see Highway Express Lines v. Jones Motor Co., 377 U.S. 217 (1964), affirming per curiam 223 F. Supp. 835 (E.D. Pa. 1963); Arrow Carrier Corp. v. United States, 375 U.S. 452 (1964), affirming per curiam 219 F. Supp. 43 (D.N.J. 1963).

124. County of Marin v. United States, 356 U.S. 412 (1958). See text accompanying note 75 supra. 


\section{A. Inadvertent Error}

The ICC has always claimed the right to recall and correct certificates where inadvertent, clerical errors have been made. In United States v. Watson Bros. Transp. Co. ${ }^{125}$ before the period under study here began, the Court affirmed a decision striking down such a correction because it involved more than a mere clerical error; the Commission was attempting to modify a certificate without affording adequate notice and hearing as required by statute. The issue also arose in United States v. Seatrain Lines, ${ }^{126}$ where the Court found that the Commission's claim of inadvertent error was being used as a smokescreen. The Commission was effecting a major change of policy and had recalled a certificate issued under the old policy in order to bring it into conformity with the new. In rejecting the Commission's maneuver, the Court reserved the question of legitimate inadvertent error.

The Supreme Court finally upheld the ICC's power to correct such legitimate errors in American Trucking Ass'ns v. Frisco Transp. Co. ${ }^{127}$ There, the ICC had issued a certificate to a railroad-owned truck line without the usual restriction to auxiliary and supplementary operations. This was during the period of ICC flux on the question of such restrictions and in the middle of its campaign to achieve a different balance between railroads and truckers than that initiated in the thirties. It is more than possible that the omission of the restriction was due less to a clerical error than confusion or conflict within the Commission. Nevertheless, the Court found it to be an inadvertent error and allowed the Commission to correct it. Perhaps the element distinguishing this case from Seatrain, from the point of view of some of the Justices, was that the recall in Seatrain was to initiate a new and unanticipated policy while that in Frisco was to enforce a longstanding practice from which Frisco could not reasonably have expected deviation. The much attenuated ghost of administrative res judicata hovers vaguely here. In any event Seatrain and Frisco between them indicate that while the Justices will allow the Commission to correct inadvertent error, the Court will ultimately decide what is or is not inadvertent.

\section{B. Suspension of Rail Rate Changes}

The Court's treatment of ICC power to suspend rail rate changes while deciding whether to approve them illustrates another important area of Court-ICC relations. The ICC has the statutory power to suspend rate changes for seven months, ${ }^{128}$ and the railroads had for years voluntarily maintained the suspension for whatever additional period the Commission required to make its decision. In 1962 , however, the railroads refused to voluntarily extend suspensions. In Arrow Transp. Co.v. Southern $R y .{ }^{129}$ a party to a rate dispute had asked a federal district court to extend an ICC suspension beyond seven months by injunction.

125. 350 U.S. 927 (1956), affirming per curiam 132 F. Supp. 905 (D. Neb. 1955).

126. 329 U.S. 424 (1947).

127. 358 U.S. 133 (1958).

128. Interstate Commerce Act $\S 15(7)$, added by 44 Stat. 1447 (1927), as amended, 49 U.S.C. $\S 15(7)(1964)$.

129. 372 U.S. 658 (1963). 
Such a request was unprecedented, but so was the railroad's refusal to voluntarily extend the suspension period.

The district and circuit courts involved refused the injunction and so did the Supreme Court. The Court found that the Mann-Elkins Act, ${ }^{130}$ in vesting the power of suspension in the ICC, contemplated that such power be exclusively with the Commission, leaving none to the courts. In addition, the Court argued that the reasonableness of rates was a question within the primary jurisdiction of the ICC, and equitable actions in the district court would, if permitted, require determinations of reasonableness in violation of the primary jurisdiction rule.

Legislative history here was not conclusive. Indeed the majority admitted this. Furthermore, the district courts would not necessarily have had to decide the reasonableness of rates. In Arrow the district court had found that the reduced rates were driving the petitioner into bankruptcy. Under its equitable powers, a court might intervene to prevent irreparable injury until the ICC reached a final judgment on reasonableness, without itself making any determination except that of irreparable injury. And the Supreme Court under its supervisory powers might have limited the district courts' intervention to just such cases. Such equitable powers would not invade the Commission's primary jurisdiction; rather they could preserve that jurisdiction by maintaining the status quo until the ICC could reach a decision. So the dissenters, Clark, Warren, and Black, argued.

Judicial modesty obviously played an important role in forming the majority. Because most rail lines would have the choice of a number of district courts, forum shopping would be encouraged. Some district courts might begin making decisions on reasonableness under the guise of determining the degree of injury. Although these issues are theoretically distinct, they tend in practice to become confused. Furthermore, a Supreme Court finding of irreparable injury would tend to prejudice the ICC inquiry; given the general policy of preserving carrier status quo, any rate which did irreparable injury would seem unreasonable for precisely this reason. ${ }^{131}$ Considering the time required for an ICC rate decision, a decision in favor of equitable relief would have brought a stream of rate cases into the federal courts. This would have tended to establish them as an important rival to ICC ratemaking, at least in the sense of making temporary rate decisions until the ICC got around to final ones. Obviously such a situation would hardly be relished by the judicially modest.

As for the swing Justices (and Justice Douglas), this case presented something of a dilemma. To grant the district courts injunctive powers would amount to allowing the ICC in conjunction with a district court to suspend a rate change indefinitely, since the district court's injunction would presumably remain in force indefinitely unless and until the ICC made a final decision. On the other hand, to deny injunctive relief would allow the ICC to approve sub silentio those rate changes it favored, but which did not meet its own standards of reasonable-

130. 36 Stat. 539 (1910).

131. While the primary consideration in ICC reasonableness determination is the applicant carrier's costs, effects on other carriers have always been considered relevant. 
ness, simply by delaying its formal decision indefinitely. The unsavory history of the Mechling Barge dispute suggests this is not simply a fanciful imagining. ${ }^{132}$

The ideal solution from the point of view of the Court's interest in keeping the ICC functioning as Congress had intended would be some method of persuading the ICC to decide its cases within the first seven months. Presumably that is what the railroads, which suddenly stopped giving the ICC more time, wanted too. The Court, in refusing the injunctions, was helping to move the Commission into the proper time limits, but with the fatal flaw of allowing the Commission the vast tactical power of using the time pressure to its own advantage. Perhaps the Commission might have been pressured more efficiently by the prospect of district court action when it fails to act within seven months than by a situation in which failure to officially decide can result in what it wants without the bother of statutory justification. On the other hand, much of the ICC's delay is, of course, simply caused by a heavy work load and a penny-pinching Congress. In light of this the majority opinion could be viewed as a piece of Supreme Court lobbying aimed at congressional approval of a higher Commission budget. Surely the prospect of irreparable injury to business firms without hope of remedy because the ICC does not have adequate staff to handle its caseload is calculated to loosen some congressional purse strings. ${ }^{133}$

\section{Remedies}

Our last area of concern has quite rightly excited more than a little interest among lawyers, but is usually viewed as an isolated instance of an interesting doctrinal problem rather than part of the overall balance of power between the Commission and the Court. T.I.M.E. Inc. v. United States ${ }^{134}$ and Hewitt-Robins Inc. v. Eastern Freight-Ways, Inc. ${ }^{135}$ focus on the problem of whether commonlaw remedies survive the congressional assignment of statutory remedies to the ICC.

T.I.M.E. is a prime example of judicial lawmaking, because the circumstances required the Court to choose between two directly opposite interpretations of a statute, both of which were fully defensible. The Motor Carrier Act does not mention judicially administered common-law remedies for unreasonable rates, although those remedies were specifically provided for in previous legislation dealing with unreasonable rail rates. ${ }^{136}$ The congressional intention of excluding such remedies in truck rate cases, therefore, would seem fairly clear. However, the Motor Carrier Act also carries a savings clause declaring that no commonlaw remedy is destroyed by the statute. ${ }^{137}$ Since there is a relatively well-known common-law remedy for unreasonable rates-reparations-the congressional intention of preserving that remedy in truck rate cases also seems fairly clear.

132. See A. L. Mechling Barge Lines y. United States, 376 U.S. 375 (1964); A. L. Mechling Barge Lines v. United States, 368 U.S. 324 (1961).

133. For another case dealing with time limits on ICC action see Pan-Atlantic S.S. Corp. v. Atlantic Coast Line R.R., 353 U.S. 436 (1957) (temporary certificates do not expire until final ICC determination on issuance of permanent certificates).

134. 359 U.S. 464 (1959).

135. 371 U.S. 84 (1962).

136. Interstate Commerce Act $\S 8,24$ Stat. 382 (1887), as amended, 49 U.S.C. $\$ 8$ (1964).

137. Interstate Commerce Act $\$ 216(j)$, added by 49 Stat. 560 (1935), 49 U.S.C. $\$ 316(j)$ (1964). 
It would be possible to go on at some length about divining true congressional intent. But in view of the indeterminacy of the statute, the voting in the cases is more significant than such an academic exercise would be. Justices Frankfurter, Harlan, Stewart, and Whittaker opted for exclusive power in the Commission with no independent judicial remedy for reparations. Justices Warren, Black, and Douglas wished to preserve the judicial remedy. Our swing Justices, Brennan and Clark, split, with Brennan's vote providing a majority for the modest wing. This absolute symmetry in voting indicates more strongly than any other factor the lawmaking quality of the decision. ${ }^{138}$

In the face of the absolute command of Congress that nothing in the statute should be read as destroying common-law remedies, the majority had to resort to a second stage of judicial lawmaking, this time at the level of administrative decisional law. The majority pointed out that it had long been acknowledged that the ICC had primary jurisdiction over the reasonableness of rates, and that Congress could not have intended courts to entertain suits which required a determination of the reasonableness of rates. Thus, the judicial remedy was not destroyed by the express provisions of the statute, but by the general principles of administrative law.

While there is some precedent for such a holding, ${ }^{139}$ the judicial hand was not as much quicker than the eye in this instance as it might have been. The primary jurisdiction doctrine is generally concerned, as its name implies, not with assigning exclusive jurisdiction to one decisional agency or another, but with questions of timing. Typically a court finds that certain determinations must be made by an administrative agency before it can reach a final judgment. It either stays its proceedings until that agency can act, or directs the parties to initiate and complete proceedings before that agency before coming into court. The primary jurisdiction doctrine is thus essentially a means of coordinating concurrent jurisdictions, not of eliminating judicial decision making in favor of administrative decision making as the majority did in TI.M.E.

The governing intention of the majority in T.I.M.E. was undoubtedly to keep the courts out of ratemaking negotiations for reasons of economic and political policy that we shall examine presently in connection with the Hewitt-Robins case. But, as so often happens in law, the purely secondary means of reaching that end, the use of the primary jurisdiction doctrine to avoid the embarrassment of a savings clause, has taken on a life of its own. T.I.M.E. has been in the long run more important for its impact in shifting the primary jurisdiction doctrine toward an exclusive jurisdiction doctrine than for its direct effect on Court-ICC rate relations. Yet the crucial vote of Justice Brennan was undoubtedly heavily influenced by the specific problem of Court-Commission relations in the rate area. Thus a full appreciation of the general doctrines of administrative law, such as primary jurisdiction, depends upon a detailed understanding of the political problems raised by interagency policymaking in specific situations.

138. The symmetry remains absolute even though the voting is 5-to-4. The modest and activist wings face each other without a single desertion from the ranks of either, and the swing group splits one against one. In terms of attitudinal groups, the score in this case was $1 \frac{112}{2}$ to $1 \frac{1}{2}$.

139. See Texas \& Pac. Ry. v. Abilene Cotton Oil Co., 204 U.S. 426 (1907). 
The Hewitt-Robins case quite clearly brings out this relation between the specific political setting and the general development of administrative law. There the problem was again whether a judicially administered common-law remedy could exist side by side with an ICC remedy. However, this time the injury to be remedied was misrouting ${ }^{140}$ rather than unreasonable rates. The Court ruled that the common-law remedy for misrouting, a suit for damages, survived the ICC's statutory authorization to issue cease and desist orders to cure each injury.

Hewitt, like TI.ME., is a classic instance of the opportunity for-indeed necessity of-judicial lawmaking. The Motor Carrier Act did not specify modes of reparation for the "unreasonable practices" it condemned, such as misrouting. The Commission urged Congress to provide such a remedy, as it has for rail and water carriage. Congress did not do so, and in 1944 the Commission declared that it would decide whether misrouting had in fact occurred and then leave the remedy for past misrouting to the courts. ${ }^{141}$ Meanwhile the Federal Power Commission had had the same problem with its governing statutes and had adopted the same solution as the ICC, determining the unreasonableness of utility rates and leaving reparations to the courts.

In I95I in the Montana-Dakota case ${ }^{142}$ the Supreme Court held that it was powerless to grant relief if the question was within the primary jurisdiction of the FPC-again a move by the judicially modest to convert primary jurisdiction into exclusive jurisdiction. Thus, subsequent to $195 \mathrm{r}$, congressional silence might reasonably be interpreted either as approving both the ICC's and the FPC's declared policies of leaving reparations questions to the courts or as intending that there should be no remedy at all. While logically correct, it is more than a little fanciful to infer from the silence of Congress the prospective approval of an anticipated extension of the rule of Montana-Dakota to the misrouting problems of the ICC. More realistically there seems to have been a potential policy conflict between two government bodies, the ICC and the Supreme Court, on which a third body, Congress, had taken no stand. It is possible, of course, to argue that the Court was not totally free to make law, being bound by its own precedent of Montana-Dakota; but that case had itself been something of a breakthrough rather than an episode in a firm and unrivaled line of precedent. Without such a firm line, the best modern view is that no single case can automatically determine the outcome of any single later case differing on its facts, even under the most compulsive view of stare decisis. ${ }^{143}$

In preserving the common-law remedy the majority of the Court overruled Montana-Dakota, distinguished T.I.ME. on the basis of differences between routing and rates, and returned the primary jurisdiction doctrine to its original

140. The question of what constitutes misrouting is itself a complex one. Generally misrouting exists if the route chosen by the carrier results in higher cost to the shipper than would have resulted from choosing another route reasonably available to the carrier, e.g., shipping canned goods from San Francisco to Los Angeles by way of Denver.

141. Bell Potato Chip Co., 43 M.C.C. 337 (1944).

142. Montana-Dakota Util. Co. v. Northwestern Pub. Serv. Co., 341 U.S. 246 (1951).

143. See Stone, Legal System and Lawyers' Reasoning 278-81 (1964). 
meaning-the ICC first determining the reasonableness of the route and the courts then granting a remedy on the basis of that determination.

The voting in Hewitt is once again the most revealing feature. In TI.M.E. Justices Warren, Black, Douglas, and Clark had dissented. Now they formed the majority, with the addition of Justices Brennan and Goldberg. In one sense the replacement of Justices Frankfurter and Whittaker by Goldberg and White determined the decision in Hewitt. For while the two former Justices both voted against the Warren-Black wing, one of the new Justices voted with it to form a majority. But even if there had been no change in personnel, Hewitt would have been decided the way it was because of the change in Justice Brennan's vote from T.I.M.E. In that sense it was the swing Justices who decided this case and, unless Brennan has had a change of heart about TIIM.E., it can be assumed that the reason for the differing policies of T.I.M.E. and Hewitt is that Brennan does distinguish between rate remedies and routing remedies. ${ }^{144}$

There are in fact grounds for such a distinction; they suggest that Justice Brennan was deciding this case in the grand style. The distinction is not one between the complexity of rate and routing decisions. Under the primary jurisdiction doctrine, the Court will leave the reasonableness of both to the Commission. Rather the difference rests on two factors. First, under the statutes prospective rate changes are announced well in advance. If they are unreasonable, the Commission can prevent them from going into effect and thus prevent the damage before it occurs. Misroutings are, of course, not so announced, and subsequent Commission cease and desist orders can be little more than the proverbial locking of the barn door. Of course, the Commission sometimes does fail to prevent an unreasonable rate from going into effect. That is precisely why cases like T.I.M.E. arise. Generally speaking, however, unreasonable rates can be deterred or prevented by Commission hearings, whereas the common-law damage remedy is the only available deterrent and mode of compensation for misrouting.

The second difference between routing and rate remedies stems from essentially political factors-the balance of power among various government agencies and private groups. In establishing a system whereby changes in rates are announced in advance and then subject to adversary hearings before the ICC, Congress has created a complex and subtle bargaining relationship between the Commission, carriers, shippers, and rival carriers. If some participants in this process always had the prospect of achieving retroactive reductions in rates by going to court and receiving compensatory damages after Commission bargaining had been completed, the balance of power would be seriously altered. No such prob. lem exists in the misrouting area. Indeed a very serious imbalance against the shipper would exist there if he had no remedy for past misconduct on the part of the carrier, since he cannot anticipate further misconduct.

Perhaps the most interesting feature of Hewitt is that it will be read as disapproving the tendency to turn primary jurisdiction into exclusive jurisdiction,

144. If Justice Goldberg was of exactly the same view as Justices Warren, Black, Douglas, and Clark on these questions, then Hewitt in effect is a reversal of the policy of T.I.M.E. caused by changes in Court personnel, with the new majority deciding that it wished to avoid the appearance of overruling T.I.M.E. 
when in fact it may have rested on the peculiar differences between the tactical situations engendered by ICC procedures in the rate and route areas. Until the position of Justice Brennan becomes clearer, and until we have an opportunity to see how Justice Fortas will vote, the Hewitt decision remains a clouded glass. ${ }^{145}$

In any event, T.I.M.E. and Hewitt can hardly be considered minor, technical decisions exhibiting a peculiarly high level of deference to the ICC, particularly when the minority of T.I.M.E. has become the majority of Hewitt.

\section{CONCLusion}

This survey of the Warren Court's ICC decisions is meant not as a startling exposé, but as a summary of important legal data which somehow has failed to attract sufficient scholarly attention in the last few years. We do not find a superactive Court bent on destroying the ICC. On the other hand, neither do we find anything like that degree of deference to the Commission that the widely accepted clichés would lead us to expect. All this will come as no great shock to those who especially concentrate on the law of transportation. But for the general student of administrative law, and especially for those who devote themselves to the study of the Supreme Court, there is enough here to suggest strongly that Court-ICC relations are an important part of the work of the Court which should no longer be neglected.

It is significant that in the first ICC case of the I964 term the Court reversed the Commission on a rate question that arose as part of the railroads' response to the most recently initiated Commission policy on a crucial transportation problem-piggybacking. ${ }^{146}$ This may not be the great constitutional Supreme Court, desegregating the nation and reapportioning the states, but it is a Court that still seems to intervene on nearly every major policy question with which the Commission deals. Surely this segment of the Court's work must be taken into account in assessing the overall role of the Supreme Court, rather than swept into limbo as a minor fossil remaining from the Court's earlier constitutional concern with interstate commerce and due process or as part of the esoterica of administrative law. The essential activism of the Court toward the ICC, and hence the importance of this area of litigation for an understanding of the Court, has been largely obscured by a failure to differentiate the mass of ICC decisions on routine matters, which the Court passes over in silence, from those decisions that involve major changes in public policy, where the Court does quite consistently intervene.

The Court's interventions sometimes result in major and sometimes only in marginal changes of government policy. Sometimes the Court's policies stick and sometimes they are reversed by Congress or evaded by the Commission. All this, of course, is to say that the Court is a part of the interagency politics and interest bargaining that characterizes most of the policymaking process in Washington. Some of the Justices are obviously working in the grand style, seeking to

145. Justice Clark wrote the opinion in Flewitt and so may have also adopted the middle ground distinction between rates and routes that we have imputed to Justice Brennan. This would hardly be surprising in view of his overall pattern of voting.

146. All States Freight, Inc. v. New York, N.H. \& H.R.R., 379 U.S. 343 (1964). 
make the best possible adjustment of the law to the needs of society. Others are eschewing the role of policymaker, but attempting to keep the Commission firmly within what they divine to be the intentions of Congress. In one sense these two judicial styles are in direct conflict. One assumes responsibility for changing the law to meet new needs. The other refuses that responsibility and indeed resolutely defends obsolescent laws against attempts of others to change them until the "proper" agency, Congress, gets around to doing so. But both styles are likely to lead the Supreme Court into an active role vis-à-vis the ICC, as one group of Justices pursues policies differing somewhat from the Commission's and the other seeks to prevent the Commission from pursuing policies differing somewhat from those initially laid down by Congress.

We have no scale for measuring judicial or indeed any sort of political power or influence. It is not possible to say precisely how much lawmaking the Supreme Court does in the transportation field. Based on a review of the cases it is, however, possible to say that the Supreme Court does play a significant role in the making of transportation policy and that this role must consequently be taken into account by those seeking to understand the place of the Supreme Court in American politics and the role of the Justices in the development of administrative law. 